\title{
Systematic revision and cladistic analysis of the Patagonian genus Platesthes (Coleoptera: Tenebrionidae)
}

\author{
Gustavo E. FLORES \\ Laboratorio de Entomología, Instituto Argentino de Investigaciones de las Zonas Áridas (IADIZA, CRICYT), Casilla de Correo 507, \\ 5500 Mendoza, Argentina; e-mail: gflores@lab.cricyt.edu.ar
}

Key words. Coleoptera, Tenebrionidae, Pimeliinae, Praocini, Platesthes, South America, Patagonian steppes, distribution, biology

\begin{abstract}
The genus Platesthes Waterhouse, 1845 (Pimeliinae: Praocini), distributed in the Patagonian steppes in southern Argentina and Chile, is revised. A phylogeny of its 13 species is proposed, based on 48 morphological characters. The cladistic analysis provides one most parsimonious cladogram showing that three unambiguous synapomorphic characters of external morphology and male genitalia support the monophyly of Platesthes. This article includes a redescription of the genus, redescriptions of its species, an identification key, habitus photographs of the most representative species, illustrations of external morphology, genital features and metendosternites, a cladogram and distribution maps. A discussion of the biogeography and status of conservation of Platesthes in the Patagonian steppes and in Central Chile is presented. A new Platesthes species is described: P. neuquensis sp. $\mathrm{n}$. and P. hirtipes Kulzer, 1962 stat. n. is elevated to species status. Other valid species of the genus are: $P$. depressa (Guérin-Ménéville, 1841), $P$. similis Kulzer, 1956, P. unicosta Kulzer, 1956, P. nigra Kulzer, 1956, P. pilosa Kulzer, 1956, P. vidali Peña, 1986, P. burmeisteri Haag-Rutenberg, 1877, P. granulipennis Kulzer, 1956, P. kuscheli Kulzer, 1958, P. humeralis Kulzer, 1958 and P. silphoides Waterhouse, 1845 (type species), for which a lectotype is designated.
\end{abstract}

\section{INTRODUCTION}

The genus Platesthes Waterhouse, 1845 belongs to the Praocini, an endemic Neotropical tribe of Pimeliinae with 139 species arranged in 12 genera, which inhabit arid and semiarid lands of southern South America (Kulzer, 1958; Flores, 2000a, 2001). The last revision of the tribe was made by Kulzer (1958) and a new revision is needed because one genus was not-monophyletic (Flores, 2000a), other genera were recently transferred from the Nycteliini to the Praocini (Flores, 2001) and many species still remain undescribed, some of which belong to undescribed genera. Platesthes comprises 13 species of which 12 are restricted to the Patagonian steppes between $39^{\circ}$ South and $54^{\circ}$ South in southern Argentina and Chile, and one species to Central Chile. A basic feature of the tenebrionid fauna of the Patagonian steppes is the dominance of the Neotropical tribes Nycteliini, Praocini and Scotobiini (Kuschel, 1969). Among the Praocini, endemic genera or subgenera in this area are Platesthes, Praocis (Hemipraocis) Kulzer, 1958, Praocis (Praonoda) Kulzer, 1958, and the monotypics Neopraocis Kulzer, 1958 and Asidelia Fairmaire, 1905.

Platesthes was established by Waterhouse (1845) for his new species Platesthes silphoides, who placed this genus close to the genera Gyriosomus Guérin-Ménéville, 1834 and Praocis Eschscholtz, 1829, but Lacordaire (1859) was the first to include Platesthes in the Praocini. Subsequent authors described new species (HaagRutenberg, 1877; Kulzer, 1958; Peña, 1986). The only revision of the genus, based exclusively on external morphology, was made by Kulzer (1956), who described five new species and gave a reduced distribution for the species. This study provides a revision of the genus using also characters of male and female genitalia, which are diagnostic at the generic and specific levels within the Praocini (Flores, 2000a, b, 2001) and internal skeletal anatomy, of which drawings of the metendosternite of several species of a genus of Praocini are presented for the first time. In addition, the hundreds of specimens in studied collections, gave an accurate geographic distribution of each species.

The objectives of this study are to revise Platesthes by incorporating new characters from external and internal morphology, and genital features, to describe a new species, to conduct a cladistic analysis of the species and detail their geographic distribution.

\section{MATERIAL AND METHODS}

The present study is based on examination of specimens borrowed from the following collections and curators (I follow Arnett et al., 1993 where possible for collections codens): Natural History Museum, London, UK (BMNH, Maxwell V.L. Barclay), Field Museum of Natural History, Chicago, USA (FMNH, Philip P. Parrillo), Instituto Argentino de Investigaciones de las Zonas Áridas, Mendoza, Argentina (IADIZA, Sergio Roig Juñent), Fundación e Instituto Miguel Lillo, San Miguel de Tucumán, Argentina (IMLA, María Virginia Colomo), Instituto Patagónico de Ciencias Naturales, San Martín de Los Andes, Neuquén, Argentina (IPCN, Mario O. Gentili), Museo Argentino de Ciencias Naturales Bernardino Rivadavia, Buenos Aires, Argentina (MACN, Axel O. Bachmann), Museo de La Plata, La Plata, Argentina (MLPA, Norma B. Díaz), Museo Nacional de Historia Natural, Santiago, Chile (MNNC, Mario Elgueta D.), Natural History Museum, Basel, Switzerland (NHMB, Eva Sprecher), Pedro Vidal G.H., private collection, Santiago, Chile (PVGH, Pedro Vidal G.H.), and National Museum of Natural History, Smithsonian Institution, Washington, DC, USA (USNM, Warren E. Steiner). 
Body length was measured dorsally, along the midline, from anterior margin of labrum to elytral apex. For paraproct/coxite length the ratio proposed by Doyen (1993) was used; for basal lamina of tegmen/lateral styles length, and median lobe/tegmen length the ratios proposed by Flores (1996) were used. Dissection methods are those used by Tschinkel \& Doyen (1980) for genital structures and by Flores (1997) for internal skeletal anatomy. Drawings were made with a camera lucida adapted to a stereoscopic microscope. Exact label data are cited only for the type material, and that on separate labels indicated in brackets. The distributions of the twelve species inhabiting the Patagonian steppes follow the biogeographic districts proposed by Morrone et al. (2002) within the Central Patagonia biogeographic province (Morrone, 2001). For Platesthes vidali Peña, 1986, which inhabits Central Chile, the entomofaunal regions proposed by Peña (1966a) were used. The method of cladistic analysis used is explained under the heading "Cladistic analysis".

\section{Genus Platesthes Waterhouse, 1845}

Platesthes Waterhouse, 1845: 317; Lacordaire, 1859: 215; Gemminger \& Harold, 1870: 1906 (cat.); Burmeister, 1875: 497; Haag-Rutenberg, 1877: 155; Philippi, 1887: 733 (cat.); Gebien, 1910: 262 (cat.); Bruch, 1915: 275 (cat.); Gebien, 1938: 397 (cat.); Blackwelder, 1945: 522 (cat.); Kulzer, 1956: 952, 1958: 9; Peña, 1966a: 15 (biog.), 1966b: 428 (cat.).

Type species: Platesthes silphoides Waterhouse, 1845 (monotypy).

Diagnosis. Recognized among other Praocini by the following combination of characters: maxillary palps with last segment axe-shaped; antennae longer in the male; length of antennomere 11 exceeding length of 10; pronotum with anterior angles rounded and anterior margin lacking edge, lateral margin simple and remote from disc; prosternum without apophysis, with edge on anterior margin; metasternum, mesepisternum and metepisternum with punctures; elytron with two straight, slightly raised carinae, surface punctate; epipleuron conspicuous in posterior $4 / 5$; ventral femoral surface with setae arising from punctures; basal lamina of tegmen long $(\mathrm{B} / \mathrm{E}>1.0)$; lateral styles of tegmen with setae on ventral surface, lateral margins and dorsal surface; paraprocts very long $(\mathrm{P} / \mathrm{C}>$ $3.0)$.

Redescription. Length 7.5-17.5 mm; habitus elongate to oval, flattened or convex; body glabrous or with short or long setae. Colour of body, antennae and legs black to dark brown.

Head. Prognathous; labrum with anterior margin not broadened; clypeus with round punctures, anterior margin concave, extending anterior to frontal process; frons with round or semicircular punctures; mentum subtrapezoidal, with setae; maxillary palps with last segment axe-shaped; eyes oval; antennae longer in the male; length of antennomere 11 exceeding length of 10; apical tomentose sensory patches on antennomere 9 in two areas subequal in size, on antennomere 10 in a semicircle, on antennomere 11 on distal third.

Thorax. Prothorax semi-mobile; pronotum without wrinkles, with round, semicircular or triangular punctures; anterior angles rounded, anterior margin concave, lacking edge, width of posterior margin exceeding width of anterior margin, lateral margin simple, slender, remote from disc, posterior margin not exceeding width of base of elytra, joined in central half to elytra; posterior angles not overlapping elytral humeri; prosternum without apophysis, not extended over mesosternum, with edge on anterior margin; proepisternum and prosternum with punctures; mesosternum inclined forward, separated from prosternum; mesosternum, metasternum, mesepisternum and metepisternum with punctures.

Elytron. With two straight carinae [only one species $(P$. unicosta Kulzer, 1956) has elytron with one carina]; surface punctate; lateral margin straight, conspicuous throughout; epipleuron conspicuous in posterior $4 / 5$, with edge, anterior margin not reaching elytral humeri or posterior angle of pronotum.

Legs. Procoxal separation equal to $1 / 3$ procoxal width; mesocoxal and metacoxal separations not exceeding mesocoxal and metacoxal width; distance between mesoand metacoxae exceeding half mesocoxal length; metacoxal cavity closed laterally by metasternum and sternum 3. Ventral femoral surface with setae arising from punctures. External process of distal margin of protibiae equal to length of protarsomere 1; width of distal margin of protibiae equal to $1 / 4$ or $1 / 5$ protibial length.

Internal skeletal anatomy. Tentorium with medial straight bridge (Fig. 1). Proendosternite joined to posterior part of procoxal cavities, with posterior arms short, directed posterad and broadened in posterior margin. Mesendosternite with horizontal arms short, with long, slender dorsal arms three times as long as horizontal arms, extended about half distance to tergum. Metendosternite (Figs 2-10) with arms long, extending beyond mesocoxal inflections about one third distance to tergum, stem not exceeding half metacoxal width, length of stem exceeding width, and stem narrow in basal part (Figs 3, 4, 6 ), or narrow in medial part (Figs 8, 10), or stem with parallel sides (Figs 2, 5, 7, 9), always wider in upper than basal part. Elytral-abdominal fusion accomplished by a ridge in the elytral epipleuron, which joins by a simple coaptation without interlocking with the abdominal sterna (Doyen, 1993: Fig. 205).

Pro-mesothoracic joint. Prothorax connected to mesothorax by two flexible membranes: the first one is thickened, short, connecting both apertures, pro- and mesothoracic; ventrally this membrane is attached also to the two apodemes formed internally by the mesosternalmesepisternal suture. The second membrane extends from the posterior arms of proendosternites attached to the mesocoxal inflections to the base of the horizontal arms of mesendosternite.

Male genitalia (Figs 11-14). Dorsal membrane of proctiger concave, with two sclerotized areas. Basal lamina of tegmen long $(\mathrm{B} / \mathrm{E}>1.0)$. Lateral styles of tegmen distally close, with apex wider, with setae on ventral surface, lateral margins and dorsal surface (Figs 12, 14). Median lobe moderate $(0.75<\mathrm{L} / \mathrm{T} \leq 1.00)$, sheath-shaped, with apex rounded, not narrowed proximally (Figs 11, 13).

Female genitalia (Fig. 15). Spiculum with arms "V"-shaped. Paraprocts very long $(\mathrm{P} / \mathrm{C}>3.0)$, glabrous or with setae; coxites with setae, basal lobe of coxite not extended over paraproct, baculi of coxite inclined $45^{\circ}$; 


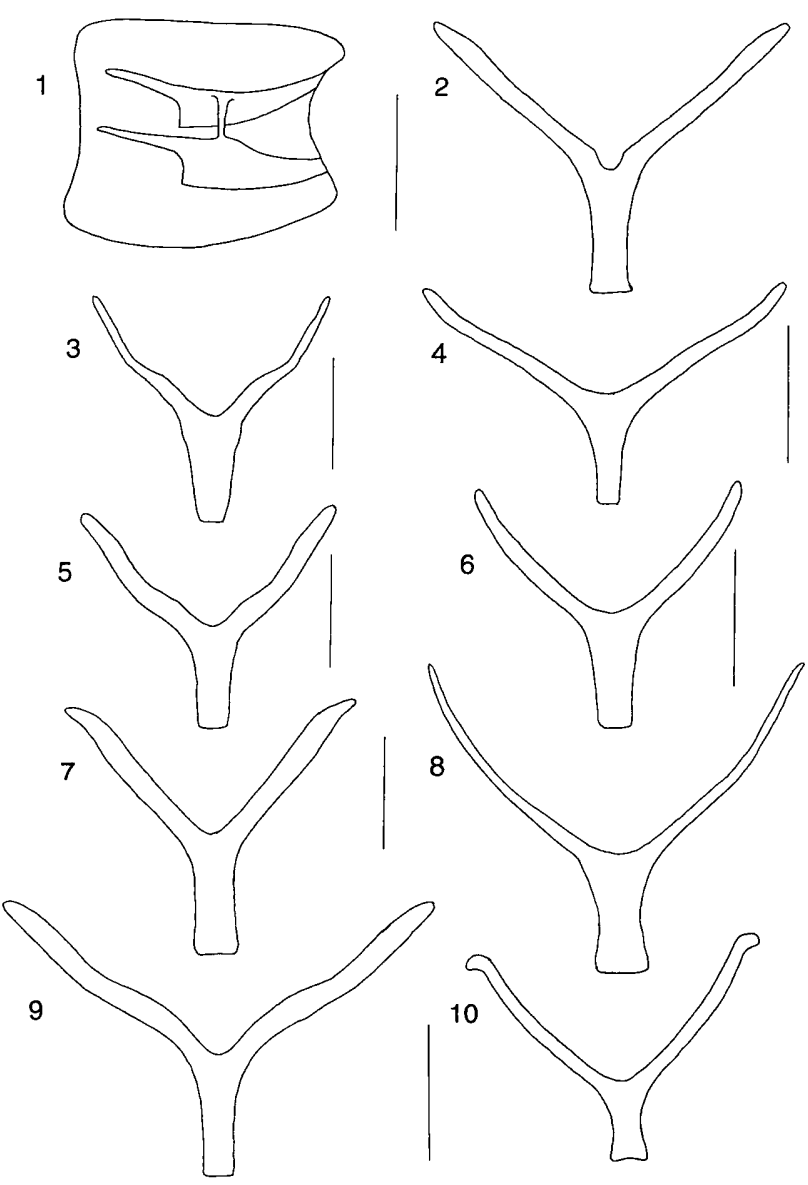

Figs 1-10. Internal skeletal anatomy of Platesthes spp. 1: Tentorium of $P$. kuscheli. 2-10: Metendosternites, posterior view. $2-P$. kuscheli; $3-P$. unicosta; $4-P$. depressa; $5-P$. similis; $6-P$. nigra $; 7-P$. pilosa $; 8-P$. vidali $; 9-P$. burmeisteri; $10-P$. granulipennis. Scales $1 \mathrm{~mm}$.

midventral sclerite distally broadened. Proctigeral baculus exceeding length of paraproct baculus. Vagina saccate. Spermathecal accesory gland longer than vagina, with duct annulate and thick. Spermatheca with four basal tubes or less, all similar in width and branching pattern.

Geographic distribution. The species of Platesthes occur from $39^{\circ}$ South to $54^{\circ}$ South in southern Argentina (Neuquén, Río Negro, Chubut, Santa Cruz, and Tierra del Fuego) and in southern Chile (Aysen and Magallanes). One species ( $P$. vidali) inhabits Central Chile between $35^{\circ} 30^{\prime}$ South and $37^{\circ} 30^{\prime}$ South.

Habitat. Twelve species occur on the xerophilous cool steppes east to the Andes, in Central Patagonia biogeographic province (Morrone, 2001) from sea level to an altitude of $1300 \mathrm{~m}$, where the annual rainfall ranges from 100 to $400 \mathrm{~mm}$ (Paruelo et al., 1998). Some of these species (P. unicosta, P. pilosa Kulzer, 1956, P. kuscheli Kulzer, 1958) live on the steppes and in the mesophylous forest of Nothofagus spp. (Fagaceae). Paula Sackmann (pers. comm.), using pitfall traps collected specimens of Platesthes pilosa near Bariloche, in Río Negro province (Argentina), at altitudes gradient between 813 to $1031 \mathrm{~m}$, annual rainfall of from 600 to $1600 \mathrm{~mm}$, on the steppes and in a mesophylous forest of Nothofagus pumilio. One species (Platesthes vidali) inhabits deciduous woodlands of Nothofagus obliqua, N. pumilio, N. antarctica, and N. alpina (Gajardo, 1994) in Central Chile west to the Andes between 1200 to $2400 \mathrm{~m}$, in the Southern Andean Mountain range entomofaunal region (Peña, 1966a).

Biology. Platesthes species have crepuscular habits, hiding during the night and the hottest hours under shrubs, logs or dry horse dung. In Santa Cruz province (Argentina), I have collected specimens of Platesthes granulipennis Kulzer, 1956 (17 km W El Calafate), specimens of P. burmeisteri Haag-Rutenberg, 1877 and P. unicosta (3 km SE El Chaltén, $400 \mathrm{~m})$, walking in the evening in steppes of Mulinum spinosum (Apiaceae), and specimens of $P$. unicosta in El Chaltén $(450 \mathrm{~m})$ under dry horse dung and in Laguna Capri (700 m), near El Chaltén, under logs in open mesophylous forest of Nothofagus pumilio.

\section{KEY TO SPECIES OF PLATESTHES}

1 Pronotum with round punctures, separated by a distance much greater than diameter of one puncture (Figs 32, 33); frons with round punctures each with a central seta. .... 2

- Pronotum with semicircular or triangular punctures, separated by a distance equal or less than diameter of one puncture (Figs 34, 35); frons with round or semicircular punctures each with a seta on posterior margin. . . . . . . 7

2 Clypeus and frons at same level; epipleuron smooth and glabrous; pronotum with round punctures each with a central seta (Fig. 32).................... 3

- Clypeus lower than frons; epipleuron punctate and with setae; pronotum with round punctures each with a seta on

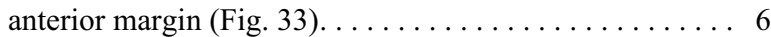

3 Elytra flat; lateral margins of pronotum raised (Fig. 36); pronotum widest behind middle (Fig. 20). . . . . . . . . P. depressa (Guérin-Ménéville, 1841)

- Elytra arched; lateral margins of pronotum not raised; pronotum widest at middle (Figs $21-23$ ). . . . . . . . 4

4 Elytron with one carina; prosternum flat. ............ ................ P. unicosta Kulzer, 1956

- Elytron with two carinae; prosternum convex. ....... 5

5 Elytron with two raised carinae reaching almost to the end of the elytron, lateral margin prominent and sharp (Fig. 16) . .................... P. similis Kulzer, 1956

- Elytron with two low carinae reaching to only half or $3 / 4$ the length of the elytron, lateral margin rounded (Fig. 17). . . . . . . . . . . . . . . . . . . P. nigra Kulzer, 1956

6 Pronotum with lateral margins not raised, posterior angles obtuse (Fig. 24), and disc convex, higher than lateral margins; clypeus straight; antennomere 10 wider than long (Fig. 18). . . . . . . . . . . . . . . P. pilosa Kulzer, 1956

- Pronotum with lateral margins very raised, posterior angles straight (Fig. 25), and disc flat, at lower level than lateral margins (Fig. 37); clypeus with anterior part bent downwards; antennomere 10 longer than wide (Fig. 19). . . . . . . . . . . . . . . . . . . . . . . . . . . P. vidali Peña, 1986

7 Pronotum with semicircular punctures (Fig. 34); elytra with round punctures with anterior margin raised, appearing as protuberances...................... 8

- Pronotum with triangular punctures (Fig. 35); elytra with round punctures with anterior margin not raised. . . . . . 9 
11

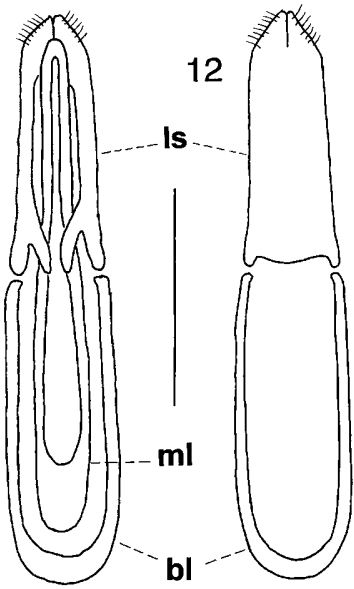

13

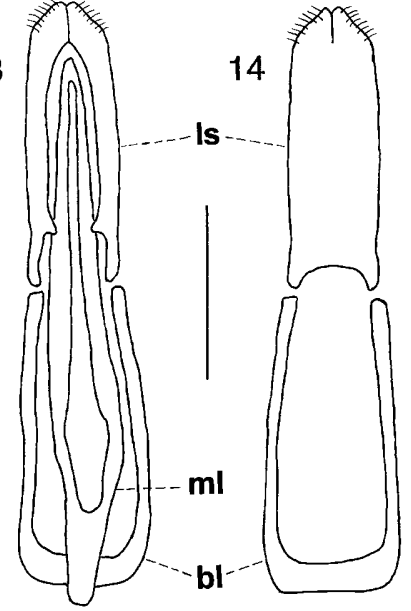

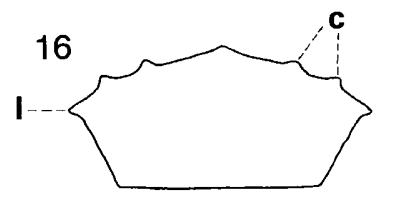

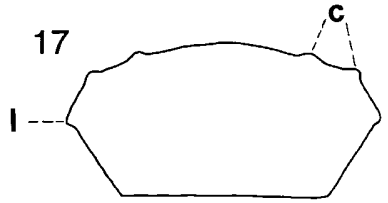

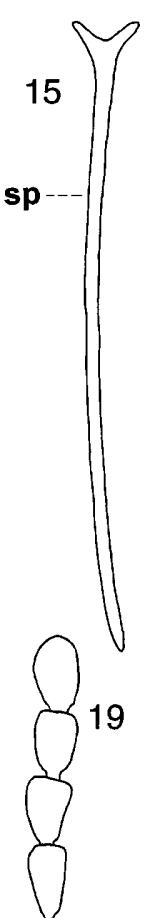

Figs 11-19. Male and female genitalia and body details of Platesthes spp. 11-14: Male genitalia, dorsal and ventral views. 11, 12 - P. granulipennis; 13, $14-P$. silphoides. 15: Ovipositor (ventral view), spiculum and internal female reproductive tract of $P$. silphoides ( $\mathrm{c}$ - coxite; o - oviduct; $\mathrm{p}$ - paraproct; $\mathrm{s}$ - spermatheca; sag - spermathecal accesory gland; $\mathrm{sp}$ - spiculum; $\mathrm{v}$ - vagina). 16, 17: Elytra, posterior view (c - carina). 16 - P. similis; 17 - P. nigra. 18, 19: Antennomeres 8-11, dorsal view. 18 - P. hirtipes; $19-$ $P$. vidali. Scales $1 \mathrm{~mm}$.

8 Ventral femoral and tibial surfaces with long dense pubescence; pseudopleuron with punctures; groove between eye and frons only on posterior half of dorsal margin of eye; frons with punctures separated by a distance much greater than diameter of one puncture (Fig. 26) . . . . . . . . . . . . . . . . . . . . . . . P. burmeisteri Haag-Rutenberg, 1877

- Ventral femoral and tibial surfaces with sparse pubescence; pseudopleuron with protuberances; groove between eye and frons on entire dorsal margin of eye; frons with punctures separated by a distance less than diameter of one puncture (Fig. 27). . . . . . . . . . . . P. granulipennis Kulzer, 1956

9 Elytral humeri very raised and expanded (Fig. 38), forming a deep depression in lateral intercostal space; labrum with anterior margin "V"-shaped; punctures of clypeus with a seta on posterior margin. . . . . . . P. humeralis Kulzer, 1958

- Elytral humeri not raised or expanded (Fig. 39); labrum with anterior margin concave; punctures on clypeus with a central seta. . . . . . . . . . . . . . . . . . . . . . . 10

10 Ventral surface of trochanters with brush-like pubescence, ventral femoral and tibial surfaces with long dense pubescence; pronotum widest at middle (Figs 28, 29). . . . . . 11

- Ventral surface of trochanters, femora and tibiae with short sparse pubescence; pronotum widest behind middle (Figs

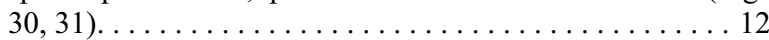

11 Frons with semicircular punctures; pronotum with lateral margins not raised (Fig. 28); ventral femoral surfaces densely setose on proximal half, ventral tibial surfaces densely setose on distal half; width of antennomere 11 equal to width of 9 (Fig. 19) . . . . . . . . P. kuscheli Kulzer, 1958

- Frons with round punctures; pronotum with lateral margins raised (Fig. 29); ventral femoral and tibial surfaces densely setose throughout; width of antennomere 11 exceeding width of 9 (Fig. 18). . . . . . . . . . P. hirtipes Kulzer, 1962
12 Clypeal suture not covered by frons; elytral carinae more approximate to lateral margin than suture. . . . . . . . . . ................. P. silphoides Waterhouse, 1845

- Clypeal suture covered by frons; elytral carinae equidistant between suture and lateral margin (Fig. 39) . . . . . . . . . . ......................... P. neuquensis sp. n.

\section{Platesthes depressa (Guérin-Ménéville, 1841)}

(Figs 4, 20, 36, 41)

Praocis depressa Guérin-Ménéville, 1841: 215; Solier, 1851: 203; Blanchard, 1853: 145.

Platesthes depressa: Lacordaire, 1859: 215; Gemminger \& Harold, 1870: 1906 (cat.); Burmeister, 1875: 497; HaagRutenberg, 1877: 155; Philippi, 1887: 733 (cat.); Berg, 1899: 60; Kolbe, 1907: 86 (cat.); Gebien, 1910: 262 (cat.); Bruch, 1915: 276 (cat.); Gebien, 1938: 397 (cat.); Blackwelder, 1945: 522 (cat.); Kulzer, 1956: 953; Peña, 1966b: 428 (cat.); Marcuzzi, 1991: 185 (biog.).

Redescription. Length $8.5-12.0 \mathrm{~mm}$. Body, antennae, and legs black to dark brown. Head. Labrum with anterior margin concave; clypeus with round punctures each with a central seta; clypeal suture not covered by frons, clypeus and frons at same level; frons with round punctures each with a central seta, separated by a distance much greater than diameter of one puncture; groove between eye and frons only on posterior half of dorsal margin of eye; antennae in the male reaching $3 / 4$ along lateral margin of pronotum, in the female reaching the middle of lateral margin of pronotum; antennomere 10 wider than long; width of antennomere 11 equal to width of 9 th. Thorax. Pronotum with round punctures each 


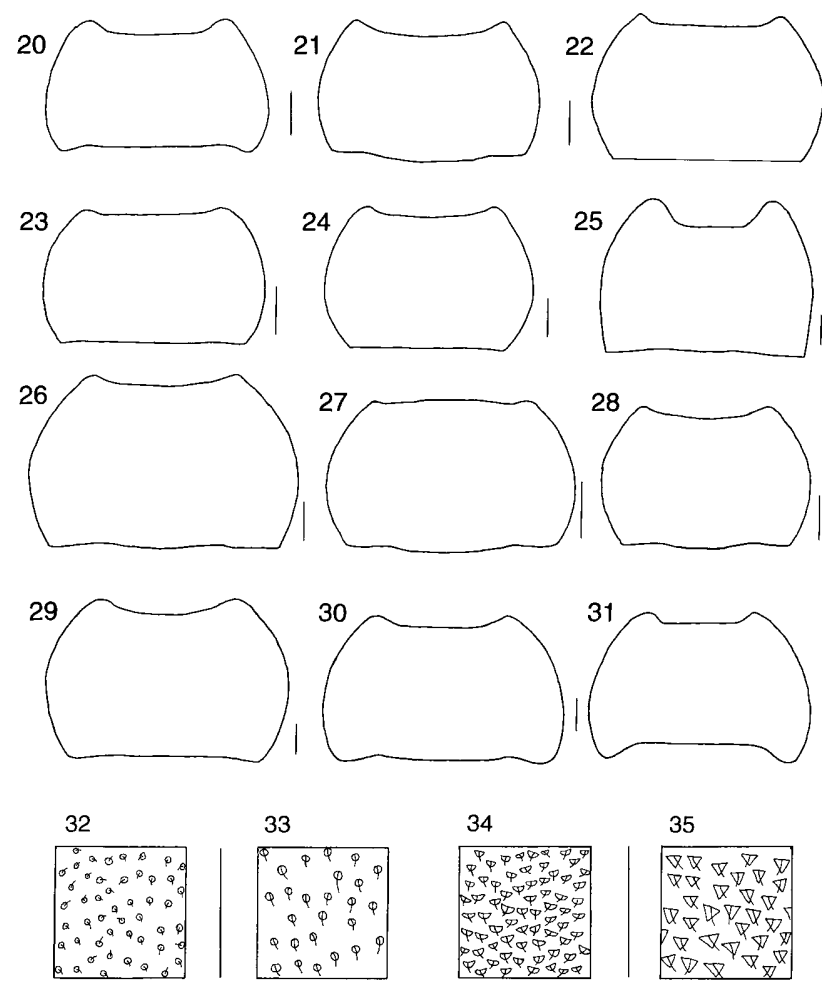

Figs 20-35. Pronotum and details of pronotal punctation of Platesthes spp. 20-31: Pronotum. 20 - P. depressa; $21-P$. unicosta; $22-P$. similis; $23-P$. nigra; $24-P$. pilosa; $25-P$. vidali; $26-P$. burmeisteri; $27-P$. granulipennis; $28-P$. kuscheli; $29-P$. hirtipes; $30-P$. silphoides; $31-P$. neuquensis. 32-35: Details of pronotal punctation. $32-P$. unicosta; $33-$ P. pilosa; $34-$ P. burmeisteri; $35-$ P. kuscheli. Scales $1 \mathrm{~mm}$.

with a central seta and separated by a distance much greater than diameter of one puncture (Fig. 32); lateral margins raised, widest behind mid point; posterior angles obtuse (Fig. 20); disc of pronotum convex, higher than lateral margins; prosternum convex. Elytron flat, with two raised carinae reaching the end of elytron, more approximate to a lateral margin, external and internal of same length or external longer than internal (Fig. 36); round punctures with anterior margin not raised; pseudopleuron with sparse punctures; epipleuron smooth and glabrous, texture similar to that of elytron, anterior quarter twice as wide as posterior half. Legs. Ventral surface of trochanters, femora and tibiae with uniform pubescence; width of distal margin of protibiae equal to $1 / 4$ protibial length; ventral surface of tarsi bearing sparse setae. Male genitalia. Lateral styles of tegmen with proximal margin ventrally concave, widest at base, and not overlapping dorsally median lobe; base of basal lamina of tegmen concave. Female genitalia. Paraprocts glabrous; apicodorsal lobe of proctiger extending about $1 / 4$ length of coxite.

Material examined. ARGENTINA: Santa Cruz: Dpto. Lago Argentino: Lago Argentino, 31.i.1953, A. Willink, 5 (IMLA); Dpto. Güer Aike: Río Gallegos, 100 m, 14.xi.1983, M. \& P. Gentili, 3 (IPCN), Monte Aymond, 27.x.1960, L.E. Peña, 3 (USNM), 1 (FMNH). Tierra del Fuego: Dpto. Río Grande: San Sebastián, 15 m, 13.xi.1983, M. \& P. Gentili, 2 (IPCN), x.1904,
R. Crawshay, 1 (BMNH), Bahía San Sebastián, 21.iv.1971, O. Flint \& G. Hevel, 2 (USNM), Cabo Espíritu Santo, 17.x.1985, A. Sobral, 1 (IADIZA), Estancia Sara, Punta Sinai, 18.x.1985, A. Sobral, 1 (IADIZA); without more precise data: xii.1959, Zapata, 1 (IADIZA). CHILE: Region XII: Magallanes: Monte Aymond, 9.iii.1958, L.E. Peña, 3 (USNM), 9.9 km N Punta Delgada (Primera Angostura), $120 \mathrm{~m}, 26 . x i .1966$, E. Schlinger \& M. Irwin, steppe assoc., 6 (FMNH), 2 (IMLA), Laguna Cabeza del Mar, 8.xi.1967, J. Cerda, 4 (FMNH), 28.viii.1976, J. Cerda, 1 (PVGH), Ruina Rica, 29.iii.1970, J. Cerda, 1 (PVGH), Punta Arenas, 1 (BMNH), Walker, 4 (BMNH), M. Wolle, 1 (NHMB), 1 (USNM), 12.ii.1967, J. Cerda, 1 (FMNH), La Vega, 21.xi.1967, J. Cerda, 1 (FMNH), Río Canelo, 16.xi.1969, J. Cerda, 3 (PVGH), $50 \mathrm{~km}$ NE Punta Arenas, 10.xii.1960, L.E. Peña, 1 (FMNH), Caleta Josefina, 5.xii.1960, L.E. Peña, 1 (FMNH), Seno Otway, 17.iii.1969, L.E. Peña, 16 (FMNH), Bahía Municiones, N Estrecho de Magallanes, 29.x.1960, L.E. Peña, 1 (FMNH), 1 (USNM), San Gregorio, 1 (USNM), without more precise data: 4 (BMNH). Tierra del Fuego: Bahía Inútil, 14.xi.1960, L.E. Peña, 21 (USNM), 1 (FMNH), 2 (IADIZA), 2 (MACN), 2 (MLPA), Manantiales (Primera Angostura), 6.xii.1960, L.E. Peña, 2 (USNM), Río Grande, 16.iii.1969, J. Cerda, 1 (PVGH), Bahía San Felipe, 8.xii.1960, L.E. Peña, 4 (USNM), Cabo Boquerón, 13.xi.1960, L.E. Peña, 1 (USNM), 1 (FMNH); without more precise data: 3 (BMNH).

Distribution. Argentina (Santa Cruz and Tierra del Fuego provinces) and Chile (Region XII) (Fig. 41), in the Fuegian district within the Central Patagonia biogeographic province.

\section{Platesthes unicosta Kulzer, 1956}

(Figs 3, 21, 32, 40)

Platesthes unicosta Kulzer 1956: 954.

Redescription. Length $8.5-12.0 \mathrm{~mm}$. Body and legs black to dark brown, antennae dark brown. Head. Labrum with anterior margin concave; clypeus with round punctures each with a central seta; clypeal suture not covered by frons, clypeus and frons at same level; frons with round punctures each with a central seta and separated by a distance much greater than diameter of one puncture; groove between eye and frons only on posterior half of dorsal margin of eye; antennae in the male reaching $3 / 4$ along lateral margin of pronotum, in the female reaching the middle of lateral margin of pronotum; antennomere 10 wider than long; width of antennomere 11 equal to width of 9 th. Thorax. Pronotum with round punctures, each with a central seta and separated by a distance much greater than diameter of one puncture (Fig. 32); lateral margins not raised, widest at mid point; posterior angles obtuse (Fig. 21); disc of pronotum convex, higher than lateral margins; prosternum flat. Elytron arched, with one raised carina reaching the end of elytron, more approximate to a lateral margin; round punctures with anterior margin not raised; pseudopleuron with sparse punctures; epipleuron smooth and glabrous, texture similar to that of elytron, anterior quarter twice as wide as posterior half. Legs. Ventral surface of trochanters, femora and tibiae with uniform pubescence; width of distal margin of protibiae equal to $1 / 4$ protibial length; ventral surface of tarsi bearing sparse setae. Male genitalia. Lateral styles of tegmen with proximal margin ventrally bisinuate, widest at base and projecting dorsally over median lobe; base of basal lamina of tegmen concave. Female genitalia. 

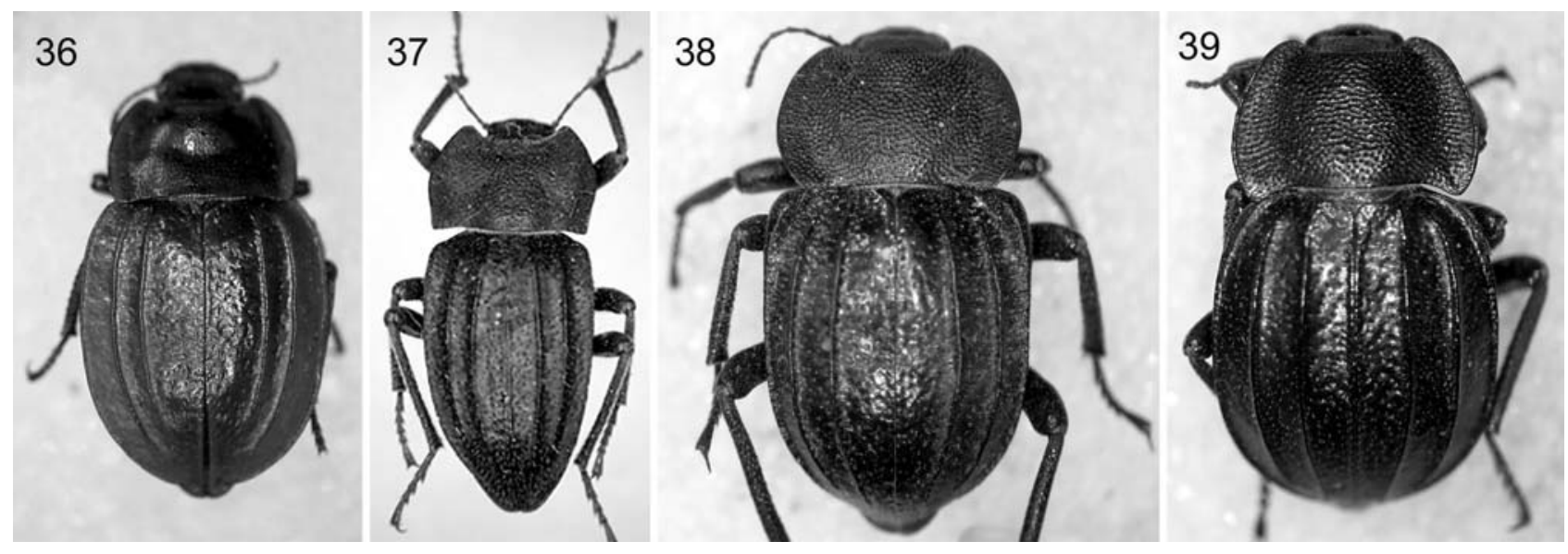

Figs 36-39. Habitus. 36 - P. depressa; 37 - P. vidali; 38 - P. humeralis; 39 - P. neuquensis.

Paraprocts glabrous; apicodorsal lobe of proctiger extending about $1 / 4$ length of coxite.

Type material. Holotype: [Estancia Fitz Roy/ Lago Viedma (Santa Cruz)/ 26.ii.1948] [Holotypus/ Platesthes/ unicosta nov./ det. H. Kulzer 1956] (NHMB). Three paratypes with the same data as holotype (1 BMNH, 1 IMLA, 1 FMNH).

Other material examined. ARGENTINA: Santa Cruz: Dpto. Lago Argentino: El Chaltén, Sendero Laguna Capri, 17.i.1998, G. Flores, 1 (IADIZA), Laguna Capri, 700 m, G. Flores, 19.i.1998, 4 (IADIZA), 1 (USNM), 1 (MACN), 1 (MLPA), El Chaltén, 450 m, 20.i.1998, G. Flores, 1 (IADIZA), 3 km SE El Chaltén, 400 m, 22.i.1998, G. Flores, 3 (IADIZA).

Distribution. Argentina: Santa Cruz province (Fig. 40), in the Fuegian district within the Central Patagonia biogeographic province.

\section{Platesthes similis Kulzer, 1956}

(Figs 5, 16, 22, 40)

Platesthes similis Kulzer 1956: 953; Peña, 1966b: 428 (cat.).

Redescription. Length 8.0-13.0 mm. Body, antennae, and legs black to dark brown. Head. Labrum with anterior margin concave; clypeus with round punctures each with a central seta; clypeal suture not covered by frons, clypeus and frons at same level; frons with round punctures each with a central seta, separated by a distance much greater than diameter of one puncture; groove between eye and frons only on posterior half of dorsal margin of eye; antennae in the male reaching 3/4 along lateral margin of pronotum, in the female reaching the middle of lateral margin of pronotum; antennomere 10 wider than long; width of antennomere 11 equal to width of 9 th. Thorax. Pronotum with round punctures each with a central seta and separated by a distance much greater than diameter of one puncture (Fig. 32); lateral margins not raised, widest at mid point; posterior angles obtuse (Fig. 22); disc of pronotum convex, higher than lateral margins; prosternum convex. Elytron arched, with two raised carinae reaching the end of elytron, more approximate to a lateral margin, external and internal of same length or external longer than internal; round punctures with anterior margin not raised; pseudopleuron with sparse punctures; epipleuron smooth and glabrous, texture similar to that of elytron, anterior quarter twice as wide as posterior half. Legs. Ventral surface of trochanters, femora, and tibiae with uniform pubescence; width of distal margin of protibiae equal to $1 / 4$ protibial length; ventral surface of tarsi bearing sparse setae. Male genitalia. Lateral styles of tegmen with proximal margin ventrally bisinuate, widest at base, and not overlapping dorsally median lobe; base of basal lamina of tegmen concave. Female genitalia. Paraprocts glabrous; apicodorsal lobe of proctiger extending about $1 / 4$ length of coxite.

Type material. Holotype: [Punta/ Arenas/ M. Wolle] [Holotypus/ Platesthes/ similis nov./ det. H. Kulzer 1956] (NHMB). Three paratypes with the same data as holotype (1 BMNH, 1 IMLA, 1 FMNH).

Other material examined. ARGENTINA: Santa Cruz: Dpto. Güer Aike: Río Turbio, 17.i.1960, A. Bachmann, 1 (IADIZA), Estancia San Elías, ii.1978, F. Roig, 1 (IADIZA), Cancha Carrera, 20.xii.1960, L.E. Peña, 3 (USNM), without more precise data: iii.1899, 4 (MACN). CHILE: Region XII: Ultima Esperanza: i.1977, F. Roig, 1 (IADIZA), Dos Lagunas, 25.i.1952, T. Cekalovic, 1 (IADIZA), 1 (IMLA), Parque Nacional Torres del Paine, Laguna Amarga, 3.xii.1966, L.E. Peña, 2 (FMNH), 14.-20.xii.1960, L.E. Peña, 6 (FMNH), Laguna Azul, 16.x.1981, L.E. Peña, 1 (FMNH), Pudeto, 28.i.1974, Bordón, 3 (IPCN), 3 (USNM), Cerro Payne, iii.1958, L.E. Peña, 1 (FMNH), 1 (USNM), Cerro Castillo, 14.xii.1960, L.E. Peña, 4 (FMNH), 20 (USNM), 2 (IMLA), 2 (MACN), 2 (MLPA), 3.xii.1966, L.E. Peña, 4 (FMNH), 22.ii.1991, 1 (PVGH), Cerro Guido, 11.ii.1957, T. Cekalovic, 2 (FMNH), 1 (USNM), x.1968, C. O’Brien, 3 (IADIZA), 14.xii.1960, L.E. Peña, 1 (USNM), 1 (FMNH), Cerro Cazador, 6.i.1955, T. Cekalovic, 1 (FMNH), 9.ii.1957, T. Cekalovic, 1 (USNM), Rincón Negro, 6.i.1963, T. Cekalovic, 1 (USNM), without more precise data: xi.1982, Barrientos, 1 (PVGH). Without more precise data: 1 (IMLA).

Distribution. Argentina (Santa Cruz province) and Chile (Region XII) (Fig. 40), in the Fuegian district within the Central Patagonia biogeographic province.

\section{Platesthes nigra Kulzer, 1956}

(Figs 6, 17, 23, 41)

Platesthes nigra Kulzer 1956: 956; Kaszab, 1964: 358 (list); Peña, 1966b: 428 (cat.).

Redescription. Length 7.5-11.0 mm. Body and legs black to dark brown, antennae dark brown. Head. Labrum with anterior margin concave; clypeus with round punc- 


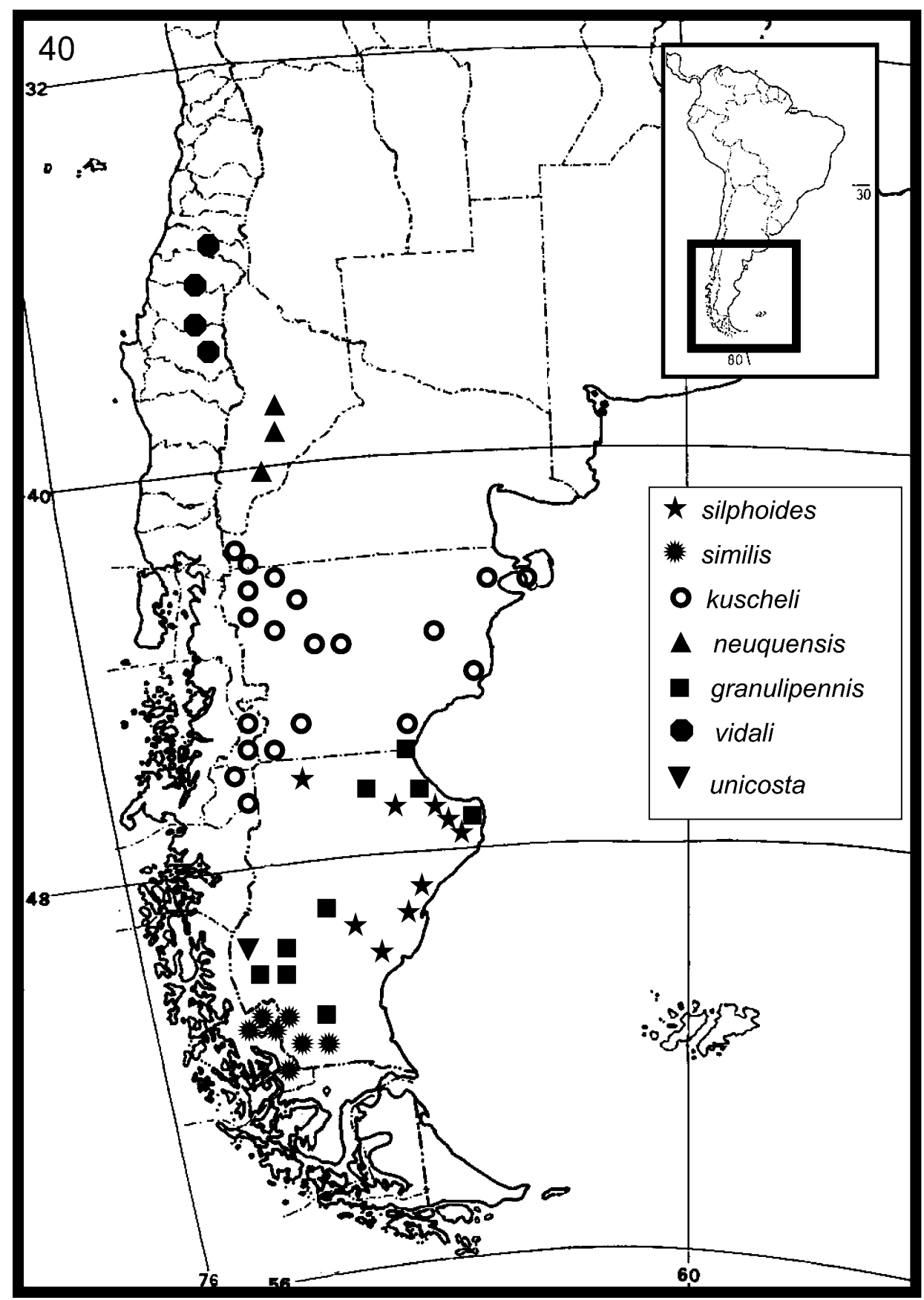

Fig. 40. Geographical distribution of seven species of Platesthes.

tures each with a central seta; clypeal suture not covered by frons, clypeus and frons at same level; frons with round punctures each with a central seta and separated by a distance much greater than diameter of one puncture; groove between eye and frons only on posterior half of dorsal margin of eye; antennae in the male reaching $3 / 4 \mathrm{f}$ lateral margin of pronotum, in the female reaching the middle of lateral margin of pronotum; antennomere 10 wider than long; width of antennomere 11 equal to width of 9 th. Thorax. Pronotum with round punctures each with a central seta and separated by a distance much greater than diameter of one puncture (Fig. 32); lateral margins not raised, widest at mid point; posterior angles obtuse (Fig. 23); disc of pronotum convex, higher than lateral margins; prosternum convex. Elytron arched, with two inconspicouous carinae reaching to only half or $3 / 4$ the length of the elytron, more approximate to a lateral margin, external and internal of same length; round punctures with anterior margin not raised; pseudopleuron with sparse punctures; epipleuron smooth and glabrous, texture similar to that of elytron, anterior quarter twice as wide as posterior half. Legs. Ventral surface of trochanters, femora and tibiae with uniform pubescence; width of distal margin of protibiae equal to $1 / 4$ protibial length; ventral surface of tarsi bearing sparse setae. Male genitalia. Lateral styles of tegmen with proximal margin ventrally 
bisinuate, widest at base, and not overlapping dorsally median lobe; base of basal lamina of tegmen concave. Female genitalia. Paraprocts glabrous; apicodorsal lobe of proctiger extending about $1 / 4$ length of coxite.

Type material. Holotype: [Lago Argentino/ Santa Cruz 15-20.ii.1949/ Argentina. Wittmer] [Holotypus/ Platesthes/ nigra nov./ det. H. Kulzer 1956] (NHMB). Three paratypes with the same data as holotype (IMLA). 18 Paratypes: [Estancia La Cristina/ (Lago Argentino)/ Santa Cruz/ 11.iii.1953/ A. Willink] (7 IMLA, 1 BMNH, 1 FMNH, 1 USNM), [Estancia La Cristina/ (Lago Argentino)/ Santa Cruz/ 14.iii.1953/ A. Willink] (2 IMLA), [Estancia La Cristina/ (Lago Argentino)/ Santa Cruz/ 18.iii.1953/ A. Willink] (4 IMLA, 1 BMNH, 1 USNM).

Other material examined. ARGENTINA: Santa Cruz: Dpto. Lago Argentino: Estancia La Cristina, 22.i.1953, A. Willink, 78 (IMLA), 2 (IADIZA), 2 (MACN), 2 (MLPA), 1.iii.1953, 26 (FMNH), Punta Bandera, 10.xii.1958, P. Miles, 4 (IADIZA), 1 (FMNH), Lago Argentino, 2.iv.1953, A. Martínez, 1 (IADIZA), Lago Argentino, Glaciar Onelli, 1.i.1959, P.W. James, 1 (BMNH). CHILE: Region XII: Ultima Esperanza: Parque Nacional Torres del Paine, 20.i.1955, T. Cekalovic, 3 (FMNH), 3 (USNM), 11.xii.1955, L. Peña, 2 (USNM), Laguna Azul, 2.ii.1974, Bordon, 1 (IPCN). Magallanes: Tres Brazos, 5.xi.1960, T. Cekalovic, 1 (FMNH).

Distribution. Argentina (Santa Cruz province) and Chile (Region XII) (Fig. 41), in the Fuegian district within the Central Patagonia biogeographic province.

\section{Platesthes pilosa Kulzer, 1956}

(Figs 7, 24, 33, 41)

Platesthes pilosa Kulzer 1956: 958; Kaszab, 1964: 358 (list).

Platesthes pubescens Bruch (nomen nudum; description not published).

Redescription. Length $10.3-15.5 \mathrm{~mm}$. Body and legs black to dark brown, antennae dark brown. Head. Labrum with anterior margin concave; clypeus with round punctures each with a central seta; clypeal suture covered by frons, clypeus lower than frons; frons with round punctures each with a central seta and separated by a distance much greater than diameter of one puncture; groove between eye and frons on entire dorsal margin of eye; antennae in the male reaching $3 / 4$ along lateral margin of pronotum, in the female reaching the middle of lateral margin of pronotum; antennomere 10 wider than long; width of antennomere 11 equal to width of 9 th. Thorax. Pronotum with round punctures each with a setae on anterior margin and separated by a distance much greater than diameter of one puncture (Fig. 33); lateral margins not raised, widest at mid point; posterior angles obtuse (Fig. 24); disc of pronotum convex, higher than lateral margins; prosternum convex. Elytron arched, with two raised carinae reaching the end of elytron, equidistant between suture and lateral margin, internal longer than external; round punctures with anterior margin not raised; pseudopleuron with abundant punctures; epipleuron punctate and with setae, texture similar to that of elytron, anterior quarter twice as wide as posterior half. Legs. Ventral surface of trochanters with brush-like pubescence, ventral femoral and tibial surfaces densely setose throughout; width of distal margin of protibiae equal to $1 / 4$ protibial length; ventral surface of tarsi bearing abundant decumbent setae. Male genitalia. Lat- eral styles of tegmen with proximal margin ventrally bisinuate, widest at base, and not overlapping dorsally median lobe; base of basal lamina of tegmen concave. Female genitalia. Paraprocts glabrous; apicodorsal lobe of proctiger extending about $1 / 4$ length of coxite.

Type material. Holotype of Platesthes pilosa: [Dr. Lendl Adolf/ Neuquén 1907] [Holotypus/ Platesthes/ pilosa nov./ det. H. Kulzer 1956] (NHMB). Syntype of Platesthes pubescens: [Rca. Argentina/ Gob. Río Negro/ C. Bruch] [Type] [Platesthes/ pubescens/ Bruch] (MACN) intended to be (designated as) the type.

Other material examined. ARGENTINA: Chubut: Dpto. Cushamen: Epuyén, 16.ix.1961, A. Kovács, 1 (BMNH), 26.vii.1962, A. Kovács, 6 (BMNH), $20 \mathrm{~km} \mathrm{~N}$ Leleque, 19.x.1960, L.E. Peña, 3 (FMNH), 1 (USNM), S El Maitén, 5.xi.1985, L.E. Peña, 1 (FMNH). Neuquén: Dpto. Los Lagos: Paso Córdoba, 20.iii.1962, J. Ripalta, 4 (IADIZA), Confluencia Traful, 690 m, 25.i.1975, M. Gentili, 2 (IPCN), 50 km N Bariloche, 2.x.1985, L.E. Peña, 1 (FMNH), Lago Nahuel Huapi, Brazo Huemul, 2.xi.1958, 4 (IADIZA), 3 (IPCN), Isla Victoria, 1.iii.1943, F. Monrós, 5 (IMLA); Dpto. Lácar, Río Caleufú, 850 m, 4.xi.1974, M. Gentili, 1 (IPCN), Lago Meliquina, 4.xii.1974, H.J. Molinari, 1 (IPCN), 21.ii.1963, 1 (IPCN). Río Negro: Dpto. Bariloche: San Carlos de Bariloche, 14.x.1960, A. Kovács, 8 (BMNH), 3.ii.1962, T. Cekalovic, 2 (FMNH), i.1988, M. Kun, 1 (IADIZA), Refugio Chalihuaco, $813 \mathrm{~m}, 41^{\circ} 11^{\prime} 27.5^{\prime \prime S}$, 71'19'30.6"W, 15.i.-10.ii.2001, P. Sackmann, 2 (IADIZA), Ruta

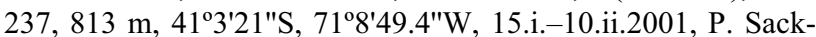
mann, 1 (IADIZA), Lago Nahuel Huapi, i.1960, Lutches, 1 (USNM); Dpto. Pilcaniyeu: Ñirihuau, 7.i.1963, 2 (IADIZA), 1 (IPCN), Alto Río Limay, ix.1957, 1 (IPCN); without more precise data: 3 (IADIZA), 21 (MACN), 5.ii.1898, C. Bruch, 3 (MACN) (these three specimens were in Bruch's collection next to the type of Platesthes pubescens).

Distribution. Argentina: Chubut, Neuquén, and Río Negro provinces (Fig. 41), in the Central district within the Central Patagonia biogeographic province.

\section{Platesthes vidali Peña, 1986}

(Figs 8, 19, 25, 37, 40)

Platesthes vidali Peña 1986: 62.

Redescription. Length $11.0-15.0 \mathrm{~mm}$. Body and legs black to dark brown, antennae dark brown. Head. Labrum with anterior margin concave; clypeus with round punctures each with a central seta; clypeal suture covered by frons, clypeus lower than frons, with anterior part bent downward; frons with round punctures each with a central seta and separated by a distance much greater than diameter of one puncture; groove between eye and frons on entire dorsal margin of eye; antennae in the male reaching $3 / 4$ along lateral margin of pronotum, in the female reaching the middle of lateral margin of pronotum; antennomere 10 longer than wide (Fig. 19); width of antennomere 11 equal to that of 9 th. Thorax. Pronotum with round punctures each with a seta on anterior margin, separated by a distance much greater than diameter of one puncture (Fig. 33); lateral margins very raised, widest behind mid point; posterior angles straight (Fig. 25); disc of pronotum flat, at lower level than lateral margins; prosternum convex. Elytron arched, with two raised carinae reaching the end of elytron, equidistant between suture and lateral margin, internal longer than external (Fig. 37); 


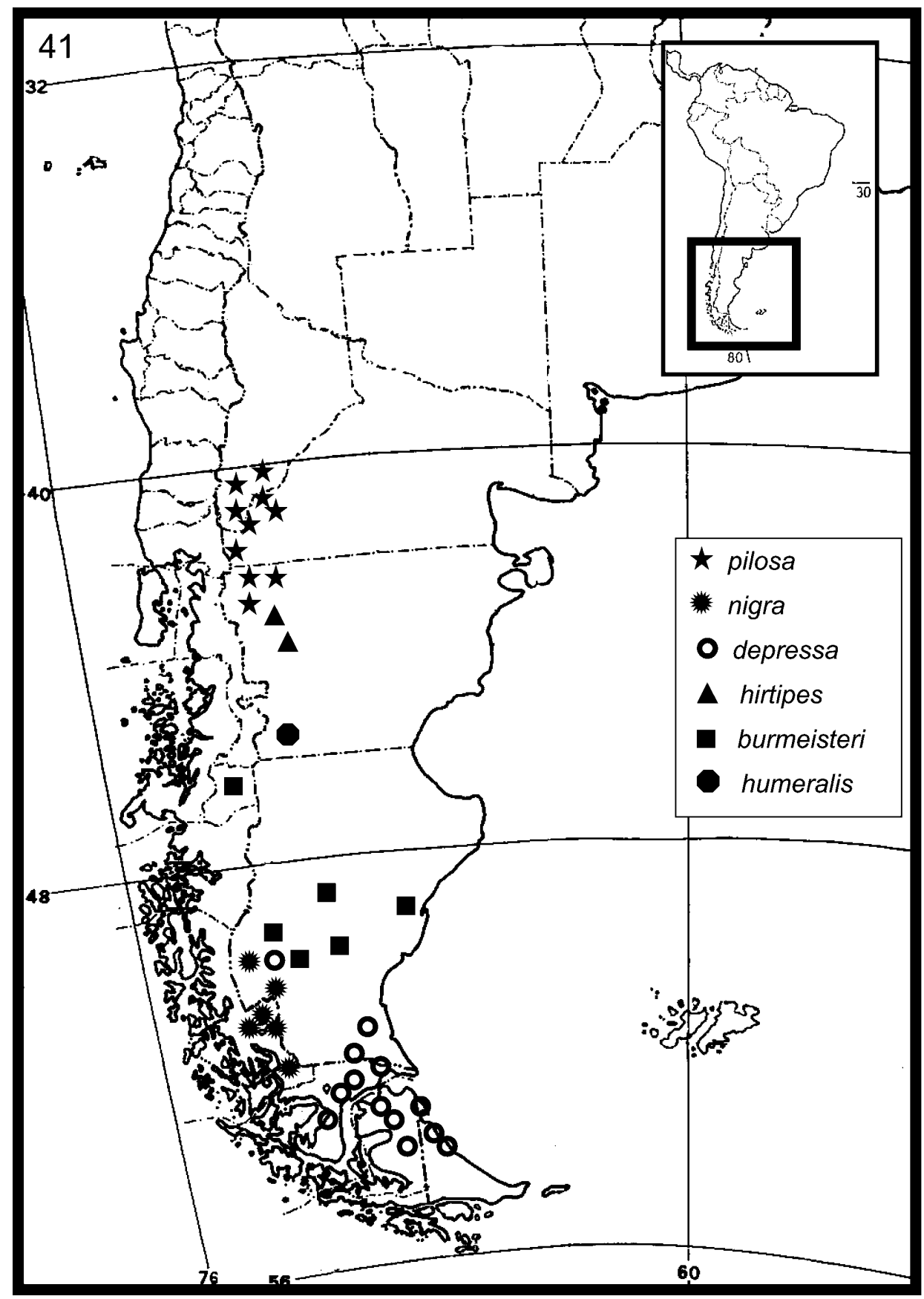

Fig. 41. Geographical distribution of six species of Platesthes.

round punctures with anterior margin not raised; pseudopleuron with abundant punctures; epipleuron punctate and with setae, texture similar to that of elytron, anterior quarter 1.5 times as wide as posterior half. Legs. Ventral surface of trochanters with brush-like pubescence, ventral femoral and tibial surfaces densely setose throughout; width of distal margin of protibiae equal to $1 / 5$ protibial length; ventral surface of tarsi bearing sparse setae. Male genitalia. Lateral styles of tegmen with proximal margin ventrally bisinuate, widest at base, and not overlapping dorsally median lobe; base of basal lamina of tegmen concave. Female genitalia. Paraprocts glabrous; apico- dorsal lobe of proctiger extending about $1 / 4$ length of coxite.

Type material. Holotype: [Alto de Vilches/ Talca $2200 \mathrm{~m} /$ 2-15.iii.1974/ leg: P. Vidal] [Platesthes/ vidali n. sp./ Holotypus/ det. L.E. Peña 1986] (FMNH). Allotype: [Alto Vilches/ Talca Chile/ 19.i.1985] [Platesthes/vidali n. sp./ Alotipo/ det. L.E. Peña 1986] (FMNH). Two paratypes with the same data as allotype (FMNH).

Other material examined. CHILE: Region VII: Talca: Alto de Vilches, 2400 m, 10.ii.1974, P. Vidal, 1 (PVGH), $2000 \mathrm{~m}$, 14.xi.1997, P. Vidal, 2 (PVGH), 10.i.1985, Pérez de Arce, 1 (MNNC), 12.i.1999, M. Gálvez, 1 (MNNC), 18.i.1999, M. Guerrero, 3 (PVGH), 1 (USNM), 1200 m, 20.xi.1999, M. Guerrero, 7 (PVGH), 2 (IADIZA), 1 (IMLA), xii.1999, M. Guerrero, 
8 (PVGH), 1 (BMNH), 1 (NHMB), 1 (USNM), 1 (MACN), 1 (MLPA), 2 (IADIZA), 10.i.2000, M. Guerrero, 2 (PVGH), iii.2000, M. Guerrero, 2 (PVGH), Alto de Vilches, Piedras Blancas, 13.xi.1999, L. Abello, 1 (MNNC); Reserva Nacional Altos de Lircay, 18.xi.2000, J. Mondaca, 3 (MNNC), $1900 \mathrm{~m}$, 6.i.2001, M. Diéguez, 2 (IADIZA). Region VIII: Parque Nacional Laguna del Laja, 22.i.1991, G. Carrasco, 1 (PVGH), Los Angeles, Cerro Abanico, 25.ii.1986, P. Vidal, 1 (PVGH).

Distribution. Chile: Regions VII and VIII (Fig. 40), in the Southern Andean Mountain range entomofaunal region.

\section{Platesthes burmeisteri Haag-Rutenberg, 1877}

(Figs 9, 26, 34, 41)

Platesthes burmeisteri Haag-Rutenberg, 1877: 156; Fairmaire, 1889: 121; Champion, 1895: 93; Kolbe, 1907: 86 (cat.); Gebien, 1910: 262 (cat.); Bruch, 1915: 275 (cat.); Gebien, 1938: 397 (cat.); Blackwelder, 1945: 522 (cat.); Kulzer, 1956: 953.

Redescription. Length 9.0-13.5 mm. Body, antennae and legs black to dark brown. Head. Labrum with anterior margin concave; clypeus with round punctures each with a central seta; clypeal suture not covered by frons, clypeus lower than frons; frons with semicircular punctures each with a seta on posterior margin and separated by a distance much greater than diameter of one puncture; groove between eye and frons only on posterior half of dorsal margin of eye; antennae in the male reaching $3 / 4$ along lateral margin of pronotum, in the female reaching the middle of lateral margin of pronotum; antennomere 10 wider than long; width of antennomere 11 equal to width of 9. Thorax. Pronotum with semicircular punctures each with a seta on anterior margin and separated by a distance equal or less than diameter of one puncture (Fig. 34); lateral margins not raised, widest at mid point; posterior angles obtuse (Fig. 26); disc of pronotum convex, higher than lateral margins; prosternum convex. Elytron arched, with two raised carinae reaching the end of elytron, equidistant between suture and lateral margin, internal longer than external; round punctures with anterior margin raised, appearing as protuberances; pseudopleuron with abundant punctures; epipleuron punctate and with setae, texture similar to that of elytron, anterior quarter twice as wide as posterior half. Legs. Ventral surface of trochanters with brush-like pubescence or with uniform pubescence, ventral femoral and tibial surfaces densely setose throughout; width of distal margin of protibiae equal to $1 / 4$ protibial length; ventral surface of tarsi bearing abundant decumbent setae. Male genitalia. Lateral styles of tegmen with proximal margin ventrally concave, widest at base, and not overlapping dorsally median lobe; base of basal lamina of tegmen concave. Female genitalia. Paraprocts with setae; apicodorsal lobe of proctiger extending about $1 / 2$ length of coxite.

Material examined. ARGENTINA: Santa Cruz: Dpto. Lago Argentino: $3 \mathrm{~km}$ SE El Chaltén, 22.i.1998, G. Flores, 2 (IADIZA), Río Santa Cruz medio, margen izquierda, 18.x.1975, M. Gentili, 3 (IPCN), 7 (IMLA), 4 (FMNH), Lago Argentino, 22.xii.1960, L.E. Peña, 1 (USNM). Dpto. Magallanes: San Julián, 29.iv.1951, L.E. Peña, 2 (FMNH). Dpto. Río Chico: Gobernador Gregores, 24.xi.1966, L.E. Peña, 12 (FMNH); without more precise data: 1 (MLPA), 2 (MACN), ii.1899, C. Bruch, 1 (MACN). Without more precise data: 4 (MACN), 8
(MLPA), 1 (IADIZA), 1 (FMNH), 1 (NHMB). CHILE: Region XI: General Carrera: Chile Chico, 1-11.ii.1983, G. Arriagada, 3 (MNNC).

Distribution. Argentina (Santa Cruz province) and Chile (Region XI) (Fig. 41), in the Central district within the Central Patagonia biogeographic province.

\section{Platesthes granulipennis Kulzer, 1956}

(Figs 10-12, 27, 40)

Platesthes granulipennis Kulzer 1956: 957.

Redescription. Length 7.5-10.0 mm. Body and legs black to dark brown, antennae dark brown. Head. Labrum with anterior margin concave; clypeus with round punctures each with a central seta; clypeal suture not covered by frons, clypeus lower than frons; frons with semicircular punctures each with a seta on posterior margin and separated by a distance smaller than diameter of one puncture; groove between eye and frons on entire dorsal margin of eye; antennae in the male reaching posterior margin of pronotum, in the female reaching $3 / 4$ along lateral margin of pronotum; antennomere 10 wider than long; width of antennomere 11 equal to that of 9 . Thorax. Pronotum with semicircular punctures each with a setae on anterior margin and separated by a distance equal or less than diameter of one puncture (Fig. 34); lateral margins not raised, widest at mid point; posterior angles obtuse (Fig. 27); disc of pronotum convex, higher than lateral margins; prosternum convex. Elytron arched, with two raised carinae reaching the end of elytron, equidistant between suture and lateral margin, internal longer than external; round punctures with anterior margin raised, appearing as protuberances; pseudopleuron with protuberances; epipleuron punctate and with setae, texture different from that of elytron, anterior quarter twice as wide as posterior half. Legs. Ventral surface of trochanters, femora and tibiae with uniform pubescence; width of distal margin of protibiae equal to $1 / 4$ protibial length; ventral surface of tarsi bearing abundant decumbent setae. Male genitalia. Lateral styles of tegmen with proximal margin ventrally bisinuate, widest at base (Fig. 12), and projecting dorsally over median lobe (Fig. 11); base of basal lamina of tegmen concave (Fig. 12). Female genitalia. Paraprocts with setae; apicodorsal lobe of proctiger extending about $1 / 2$ length of coxite.

Type material. Holotype: [El Calafate/ Santa Cruz/ 5.iii.1948] [Holotypus/ Platesthes/ granulipennis nov./ det. H. Kulzer 1956] (NHMB).

Other material examined. ARGENTINA: Chubut: Dpto. Escalante: Comodoro Rivadavia, 2 (MACN), iv.1921, G.L. Harrington, 1 (USNM), 20.i.1967, A. \& E. Willink-A. García, 3 (IMLA), 27.x.1968, T. Cekalovic, 1 (FMNH). Santa Cruz: Dpto. Lago Argentino: $17 \mathrm{~km} \mathrm{~W}$ El Calafate, 13.i.1998, G. Flores, 1 (IADIZA), Lago Argentino, 22.xii.1960, L.E. Peña, 1 (FMNH), Cañadón León, 23.xii.1960, L.E. Peña, 1 (FMNH), Lago Viedma, 1.iii.1974, Bordon, 2 (IPCN); Dpto. Güer Aike: Río Coig, 25.xi.1966, L.E. Peña, 1 (FMNH); Dpto. Río Chico: S Gobernador Gregores, 24.xi.1966, L.E. Peña, 4 (FMNH); Dpto. Deseado: Puerto Deseado, 15.i.1967, A. Willink, 3 (IMLA), Las Heras, 4.iii.1974, Bordón, 1 (IPCN), 20 km S Caleta Olivia, 12.xii.1966, L.E. Peña, 1 (FMNH). 
Distribution. Argentina: Chubut and Santa Cruz provinces (Fig. 40), in the Central district within the Central Patagonia biogeographic province.

\section{Platesthes humeralis Kulzer, 1958}

(Figs 38, 41)

Platesthes humeralis Kulzer 1958: 9.

Redescription. Length 13.0-14.0 mm. Body and legs black, antennae dark brown. Head. Labrum with anterior margin "V"-shaped; clypeus with round punctures, each with a seta on posterior margin; clypeal suture covered by frons, clypeus lower than frons; frons with semicircular punctures each with a seta on posterior margin and separated by a distance much greater than diameter of one puncture; groove between eye and frons on entire dorsal margin of eye; antennae in the male reaching $3 / 4$ of lateral margin of pronotum, in the female reaching the middle of lateral margin of pronotum; antennomere 10 wider than long; width of antennomere 11 equal to width of 9. Thorax. Pronotum with triangular punctures each with a seta on anterior margin and separated by a distance equal or less than diameter of one puncture (Fig. 35); lateral margins raised, widest behind mid point; posterior angles obtuse (Fig. 38); disc of pronotum convex, higher than lateral margins; prosternum convex. Elytron arched, with two raised carinae reaching the end of elytron, equidistant between suture and lateral margin, internal longer than external (Fig. 38); round punctures with anterior margin not raised; elytral humeri very expanded and raised (Fig. 38), forming a deep depression in lateral intercostal space; pseudopleuron with abundant punctures; epipleuron punctate and with setae, texture similar to that of elytron, anterior quarter twice as wide as posterior half. Legs. Ventral surface of trochanters, femora and tibiae with uniform pubescence; width of distal margin of protibiae equal to $1 / 4$ protibial length; ventral surface of tarsi bearing abundant decumbent setae. Male genitalia. Lateral styles of tegmen with proximal margin ventrally bisinuate, widest at base and not overlapping dorsally median lobe; base of basal lamina of tegmen concave.

Type material. Holotype: [Type] [Valle del/ Lago Blanco (Chubut)/ Patagonia] [Holotypus/ Platesthes/ humeralis nov./ det. H. Kulzer 1957] (BMNH). Allotype with the same data as holotype (NHMB).

Distribution. Argentina: Chubut province (Fig. 41), in the Central district within the Central Patagonia biogeographic province.

\section{Platesthes kuscheli Kulzer, 1958}

(Figs 1, 2, 28, 35, 40)

Platesthes kuscheli Kulzer 1958: 10; Peña, 1966b: 428 (cat.).

Redescription. Length 9.0-17.0 mm. Body and legs black to dark brown, antennae dark brown. Head. Labrum with anterior margin concave; clypeus with round punctures each with a central seta; clypeal suture covered by frons, clypeus lower than frons; frons with semicircular punctures each with a seta on posterior margin and separated by a distance much greater than diameter of one puncture; groove between eye and frons on entire dorsal margin of eye; antennae in the male reaching $3 / 4$ along lateral margin of pronotum, in the female reaching the middle of lateral margin of pronotum; antennomere 10 wider than long; width of antennomere 11 equal to that of 9. Thorax. Pronotum with triangular punctures each with a seta on anterior margin, separated by a distance equal or less than diameter of one puncture (Fig. 35); lateral margins not raised, widest at mid point; posterior angles obtuse (Fig. 28); disc of pronotum convex, higher than lateral margins; prosternum convex. Elytron arched, with two raised carinae reaching the end of elytron, equidistant between suture and lateral margin or more approximate to lateral margin than suture, internal longer than external; round punctures with anterior margin not raised; pseudopleuron with abundant punctures; epipleuron punctate and with setae, texture similar to that of elytron, anterior quarter twice as wide as posterior half. Legs. Ventral surface of trochanters with brush-like pubescence, ventral femoral surfaces densely setose on proximal half, ventral tibial surfaces densely setose on distal half; width of distal margin of protibiae equal to $1 / 4$ protibial length; ventral surface of tarsi bearing abundant decumbent setae. Male genitalia. Lateral styles of tegmen with proximal margin ventrally bisinuate, widest at base and not overlapping dorsally median lobe; base of basal lamina of tegmen concave. Female genitalia. Paraprocts glabrous; apicodorsal lobe of proctiger extending about $1 / 4$ length of coxite.

Type material. Holotype: [Balmaceda/ Aysén $45^{\circ} 54^{\prime} / 20$-II1957 Kuschel] [Holotypus/ Platesthes/ kuscheli nov./ det. H. Kulzer 1957] (NHMB). Two paratypes: [Valle del/ Lago Blanco (Chubut)/ Patagonia] (BMNH).

Other material examined. ARGENTINA: Chubut: Dpto. Cushamen: La Hoya, 800-1350 m, 24.ii.1979, Misión Científica Danesa, 2 (FMNH), Epuyén, 26.iii.1962, A. Kovács, 1 (BMNH), El Maitén, 16.x.1962, A. Kovács, 1 (BMNH), 16.ix.1961, A. Kovács, 1 (BMNH); Dpto. Futaleufú: Parque Nacional Los Alerces, La Portada, 14.iii.1974, Bordón, 3 (IPCN), 20 km S Esquel, 2.xi.1990, L.E. Peña, 1 (PVGH), N Esquel km 1480, 1000 m, 7.ii.1999, P. Vidal, 1 (PVGH); Dpto. Languiñeo: Manantiales, 6-XI-1985, L.E. Peña, 6 (FMNH), 45 km W Tecka, 660 m, 6.ii.1999, P. Vidal, 2 (PVGH), 113 km E Tecka, $500 \mathrm{~m}, 43^{\circ} 45^{\prime} 14^{\prime \prime S}, 69^{\circ} 37^{\prime} 56^{\prime \prime} \mathrm{W}, 15 . i i .1999$, P. Vidal, 6 (PVGH); Dpto. Río Senguer: Río Mayo, INTA, 4541'S, $70^{\circ} 16^{\prime} \mathrm{W}, 10 . i .1998$ to $10.1 \mathrm{v} .1998$, pitfall, F. Guerrieri, 6 (IADIZA); Dpto. Paso de Indios: Cerro Negro, Fortuna, 1 (MACN); Dpto. Gaiman: Dique Ameghino, 1.xi.1973, R. Foerster, 1 (IPCN), 23.iv.1997, M. Archangelsky-D. Rojas Lanús, 1 (IADIZA); Dpto. Biedma: Península Valdés, 12.xi.1985, L.E. Peña, 1 (FMNH), Puerto Pirámides, 1.-5.xi.1983, S. Roig, 3 (IADIZA), Puerto Madryn, 7.xi.1990, L.E. Peña, 4 (PVGH); Dpto. Florentino Ameghino: Cabo Raso, 17.xi.1985, L.E. Peña, 1 (FMNH); Dpto. Escalante: Comodoro Rivadavia, 20.i.1967, A. \& E. Willink, A. García, 1 (IMLA); without more precise data: 3 (MLPA), xi.1963, A. Giai, 13 (IADIZA). Río Negro: Dpto. Bariloche: Lago Escondido, 19.xi.1961, A. Kovács, 4 (BMNH), El Manso, 14.i.1960, A. Kovács, 2 (BMNH); without more precise data: 1 (IADIZA). Without more precise data: 1 (MLPA), 1 (FMNH). CHILE: Region XI: General Carrera: Balmaceda, 22.ix.1963, T. Cekalovic, 1 (FMNH), 23.xi.1963, T. Cekalovic, 4 (FMNH), Río Galera, 19.i.1961, L.E. Peña, 28 (FMNH), 14 (USNM), 4 km W Coihaique, 22.i.1968, O'Brien, 1 (FMNH); Chile Chico, 24.-31.xii.1960, L.E. Peña, 4 (FMNH), 23.xi.1966, L.E. Peña, 1 (FMNH), 12.ii.1982, J. Escobar, 2 (FMNH), x.1985, S. Ocare, 1 (FMNH), 10 km N Puerto Ibáñez, 
15.-17.i.1961, L.E. Peña, 217 (USNM), 2 (IMLA), 2 (MACN), 2 (MLPA), 6 (IADIZA).

Distribution. Argentina (Chubut, Río Negro, and Santa Cruz provinces) and Chile (Region XI) (Fig. 40), in the Central district within the Central Patagonia biogeographic province.

Platesthes hirtipes Kulzer, 1962 stat. n.

(Figs 18, 29, 41)

Platesthes silphoides hirtipes Kulzer 1962: 86.

Redescription. Length $14.0-17.5 \mathrm{~mm}$. Body black, elytral carinae and legs black to dark brown, antennae dark brown. Head. Labrum with anterior margin concave; clypeus with round punctures each with a central seta; clypeal suture covered by frons, clypeus lower than frons; frons with round punctures each with a seta on posterior margin and separated by a distance much greater than diameter of one puncture; groove between eye and frons on entire dorsal margin of eye; antennae in the male reaching $3 / 4$ along lateral margin of pronotum, in the female reaching the middle of lateral margin of pronotum; antennomere 10 wider than long; width of antennomere 11 exceeding width of 9 (Fig. 18). Thorax. Pronotum with triangular punctures each with a seta on anterior margin, separated by a distance equal or less than diameter of one puncture (Fig. 35); lateral margins raised, widest behind mid point; posterior angles obtuse (Fig. 29); disc of pronotum convex, higher than lateral margins; prosternum convex. Elytron arched, with two raised carinae reaching the end of elytron, equidistant between suture and lateral margin, internal longer than external; round punctures with anterior margin not raised; pseudopleuron with abundant punctures; epipleuron punctate and with setae, texture similar to that of elytron, anterior quarter twice as wide as posterior half. Legs. Ventral surface of trochanters with brush-like pubescence, ventral femoral and tibial surfaces densely setose throughout; width of distal margin of protibiae equal to $1 / 4$ protibial length; ventral surface of tarsi bearing abundant decumbent setae. Male genitalia. Lateral styles of tegmen with proximal margin ventrally concave, widest at base and not overlapping dorsally median lobe; base of basal lamina of tegmen straight. Female genitalia. Paraprocts glabrous; apicodorsal lobe of proctiger extending about $1 / 4$ length of coxite.

Type material. Holotype: [Sierra Tepuel (Tecka)/ Chubut/ Argentina/ 11.iii.1961/ Coll: L.E. Peña] [Holotypus/ Platesthes/ silphoides $\mathrm{ssp}$./ hirtipes $\mathrm{n} . /$ det. H. Kulzer 1961] (FMNH). Allotype (FMNH) and two paratypes (1 NHMB, 1 IADIZA) with the same data as holotype. Three paratypes: [Tecka/ Chubut/ Argentina/ 11.iii.1961/ Coll: L.E. Peña] (3 USNM).

Other material examined. ARGENTINA: Chubut: Dpto. Languiñeo: Sierra Tepuel (Tecka), 11.iii.1961, L.E. Peña, 1 (FMNH).

Distribution. Argentina: Chubut province (Fig. 41), in the Central district within the Central Patagonia biogeographic province.

\section{Platesthes silphoides Waterhouse, 1845}

(Figs 13-15, 30, 40)

Platesthes silphoides Waterhouse, 1845: 319; Lacordaire, 1859:

215 [as synonym of Platesthes depressa (Guérin-Ménéville,

1841)]; Gemminger \& Harold, 1870: 1906 (cat.) [as synonym of Platesthes depressa]; Burmeister, 1875: 497 [as synonym of Platesthes depressa]; Haag-Rutenberg, 1877: 155 [as synonym of Platesthes depressa]; Fairmaire, 1883: 496; 1889: 120; Philippi, 1887: 733 (cat.) [as synonym of Platesthes depressa]; Kolbe, 1907: 86 (cat.); Gebien, 1910: 262 (cat.); Bruch, 1915: 276 (cat.); Gebien, 1938: 397 (cat.); Blackwelder, 1945: 522 (cat.); Kulzer, 1956: 952.

Redescription. Length 10.0-15.0 mm. Body, antennae and legs black to dark brown. Head. Labrum with anterior margin concave; clypeus with round punctures each with a central seta; clypeal suture not covered by frons, clypeus lower than frons; frons with round punctures each with a seta on posterior margin and separated by a distance much greater than diameter of one puncture; groove between eye and frons on entire dorsal margin of eye; antennae in the male reaching $3 / 4$ along lateral margin of pronotum, in the female reaching the middle of lateral margin of pronotum; antennomere 10 wider than long; width of antennomere 11 equal to width of 9. Thorax. Pronotum with triangular punctures each with a seta on anterior margin and separated by a distance equal or less than diameter of one puncture (Fig. 35); lateral margins raised, widest behind mid point; posterior angles obtuse (Fig. 30); disc of pronotum convex, higher than lateral margins; prosternum convex. Elytron arched, with two raised carinae reaching the end of elytron, more approximate to lateral margin than suture, internal longer than external; round punctures with anterior margin not raised; pseudopleuron with abundant punctures; epipleuron punctate and with setae, texture similar to that of elytron, anterior quarter twice as wide as posterior half. Legs. Ventral surface of trochanters, femora, and tibiae with uniform pubescence; width of distal margin of protibiae equal to $1 / 4$ protibial length; ventral surface of tarsi bearing abundant decumbent setae. Male genitalia. Lateral styles of tegmen with proximal margin ventrally concave, widest at distal third (Fig. 14) and not overlapping dorsally median lobe (Fig. 13); base of basal lamina of tegmen straight (Fig. 14). Female genitalia. Paraprocts glabrous; apicodorsal lobe of proctiger extending about $1 / 4$ length of coxite.

Type material. Lectotype: [Type] [Port Desire] [Platesthes/ silphoides/ Waterh. Ann. 16. 319] (BMNH). To fix the current interpretation of this name and to ensure stability, I am hereby designating this lectotype: [Lectotypus/ Platesthes silphoides/ Waterhouse, 1845/ Des. G. Flores 2002].

Other material examined. ARGENTINA: Chubut: without more precise data: 1 (MLPA), 3.vi.1961, A. Kovacs, 1 (BMNH), 22.iv.1975, A. Kovacs, 1 (FMNH). Santa Cruz: Dpto. Lago Buenos Aires: $50 \mathrm{~km} \mathrm{~S}$ Río Mayo (Chubut), 24.x.1960, L.E. Peña, 1 (FMNH); Dpto. Deseado: Puerto Deseado, Donat, 1 (MACN), Tehuelches, Donat, 1 (MACN), Ea. La Madrugada, N Puerto Deseado, 24.xi.1985, L.E. Peña, 1 (FMNH), Biedma, 24.x.1960, L.E. Peña, 1 (USNM); Dpto. Magallanes: San Julián, 22.v.1924, P. Saggero, 5 (MLPA), 1 (IADIZA), $50 \mathrm{~km} \mathrm{~N} \mathrm{San}$ Julián, 24.x.1960, L.E. Peña, 2 (FMNH), 1.ii.1998, G. Flores, 1 (IADIZA); Dpto. Corpen Aike: Ea. El Chonque, 24.xi.1966, L.E. Peña, 1 (FMNH), Comandante Piedrabuena, 26.x.1960, L.E. Peña, 1 (USNM); without more precise data: 1 (NHMB), 1 (MACN). Without more precise data: 2 (MACN). 
Distribution. Argentina: Chubut and Santa Cruz provinces (Fig. 40), in the Central district within the Central Patagonia biogeographic province.

\section{Platesthes neuquensis sp. $\mathbf{n}$.}

(Figs 31, 39, 40)

Diagnosis. Pronotum with triangular punctures each with a setae on anterior margin, separated by a distance equal or less than diameter of one puncture; clypeal suture covered by frons, clypeus lower than frons; frons with round punctures each with a seta on posterior margin; lateral margins of pronotum raised, widest behind mid point; elytra with two raised carinae equidistant between suture and lateral margin.

Description. Length $12.0-15.0 \mathrm{~mm}$. Body and legs black to dark brown, antennae dark brown. Head. Labrum with anterior margin concave; clypeus with round punctures each with a central seta; clypeal suture covered by frons, clypeus lower than frons; frons with round punctures each with a seta on posterior margin and separated by a distance much greater than diameter of one puncture; groove between eye and frons on entire dorsal margin of eye; antennae in the male reaching $3 / 4$ along lateral margin of pronotum, in the female reaching the middle of lateral margin of pronotum; antennomere 10 wider than long; width of antennomere 11 equal to width of 9. Thorax. Pronotum with triangular punctures each with a setae on anterior margin and separated by a distance equal or less than diameter of one puncture (Fig. 35); lateral margins raised, widest behind mid point; posterior angles obtuse (Fig. 31); disc of pronotum convex, higher than lateral margins; prosternum convex. Elytron arched, with two raised carinae reaching the end of elytron, equidistant between suture and lateral margin, internal longer than external (Fig. 39); round punctures with anterior margin not raised; pseudopleuron with abundant punctures; epipleuron punctate and with setae, texture similar to that of elytron, anterior quarter twice as wide as posterior half. Legs. Ventral surface of trochanters, femora and tibiae with uniform pubescence; width of distal margin of protibiae equal to $1 / 4$ protibial length; ventral surface of tarsi bearing abundant decumbent setae. Male genitalia. Lateral styles of tegmen with proximal margin ventrally bisinuate, widest at base and not overlapping dorsally median lobe; base of basal lamina of tegmen straight. Female genitalia. Paraprocts glabrous; apicodorsal lobe of proctiger extending about $1 / 4$ length of coxite.

Etymology. Named "neuquensis" for the Argentinian province Neuquén in which all the type specimens were collected.

Type material. Holotype, male: [Leg. M. Gentili] [Collón Curá, Neuquén, Arg./ 29.xii.1958/ Col. H.J. Molinari] [HOLOTYPUS male/ Platesthes/ neuquensis n. sp./ Det. G. Flores 2003] (IADIZA). Allotype, female, with the same data as holotype (IADIZA). Two paratype females: [Zapala, Neuquén/ 1-47 Z.1948/ Hayward y Willink] [PARATYPUS female/ Platesthes/ neuquensis n. sp./ Det. G. Flores 2003] (IMLA). Two paratype females: [Leg. M. Gentili] [Marucho, Nq., Arg./ 8.xii.1966/ Col. H.J. Molinari] [PARATYPUS female/ Platesthes/neuquensis $\mathrm{n}$. sp./ Det. G. Flores 2003] 1 (IADIZA), 1 (MACN).
Distribution. Argentina: Neuquén province (Fig. 40), in the Payunia district within the Central Patagonia biogeographic province.

\section{CLADISTIC ANALYSIS}

Methods. Outgroups. Character polarity was determined by the outgroup comparison method (Nixon \& Carpenter, 1993). Outgroups were used to provide a root for the cladogram and to test the monophyly of Platesthes, not to explore the sister group relationships of Platesthes. Since there is no phylogeny for the genera of Praocini, the outgroups chosen within Praocini were the genera Praocis, Antofagapraocis Flores, 2000, Falsopraocis Kulzer, 1958 and Platyholmus Solier, 1840. The present analysis was based on 17 terminal units: 13 species of Platesthes plus the following outgroup species: Praocis rufipes Eschscholtz, 1829 (type species), Antofagapraocis subnudus Flores, 2000, Falsopraocis ricardae (Solier, 1851) (type species) and Platyholmus uspallatensis Fairmaire, 1883.

Characters. Of the 48 characters used 41 were features of external morphology, five of male genitalia and two of female genitalia (Appendix 1). The distribution of states among the terminal taxa is indicated in the data matrix (Appendix 2). Multistate characters 7, 9, 16, 19, 22, 27, $29,30,34,37,39,42$ and 44 were treated as non-additive because it was not possible to make a correlation between apomorphic states. Multistate characters 6, 11, 12, 14, 15, 33 and 40 were treated as additive and coded according to Strong \& Lipscomb (1999). The rule for ordering, in which conditions are arranged in a graded linear sequence from one to another through intermediates, is called the method of intermediates (Wilkinson, 1992); it assumes that small changes in a character are more likely to occur than large changes. In characters 6 (punctures on the frons) and 15 (punctures on the pronotum) the states absent (0) and round with a central seta (Fig. 32) (6.1, 15.1) are present in other genera of Praocini (the last also in four species of Platesthes), while the states round with a seta on anterior (pronotum)/posterior (frons) margin (Fig. 33) $(6.2,15.2)$, semicircular with a seta on anterior (pronotum)/posterior (frons) margin (Fig. 34) (6.3, 15.3) and triangular with a seta on anterior margin (Fig. 35) (15.4) are unique to species of Platesthes within Praocini. I considered the absence of punctures plesiomorphic for Praocini and that the states 2, 3 and 4 evolved in sequence from the state 1 . For the different states exhibited by the elytral carinae (characters 22-24), the absence of carinae was coded only once in the character 22 to avoid repeating this state three times and the consequent heavy weighting of this character state. In characters 23 and 24 the absence of carinae was coded as inapplicable (-) for the species Praocis rufipes, Antofagapraocis subnudus and Platyholmus uspallatensis. The same for the character state "absence of punctures" on frons and pronotum, which was coded only once in the character 6 (punctures on frons) and character 15 (punctures on pronotum) and coded as inapplicable (-) in characters 7 and 16 for the species Platyholmus uspallatensis. 


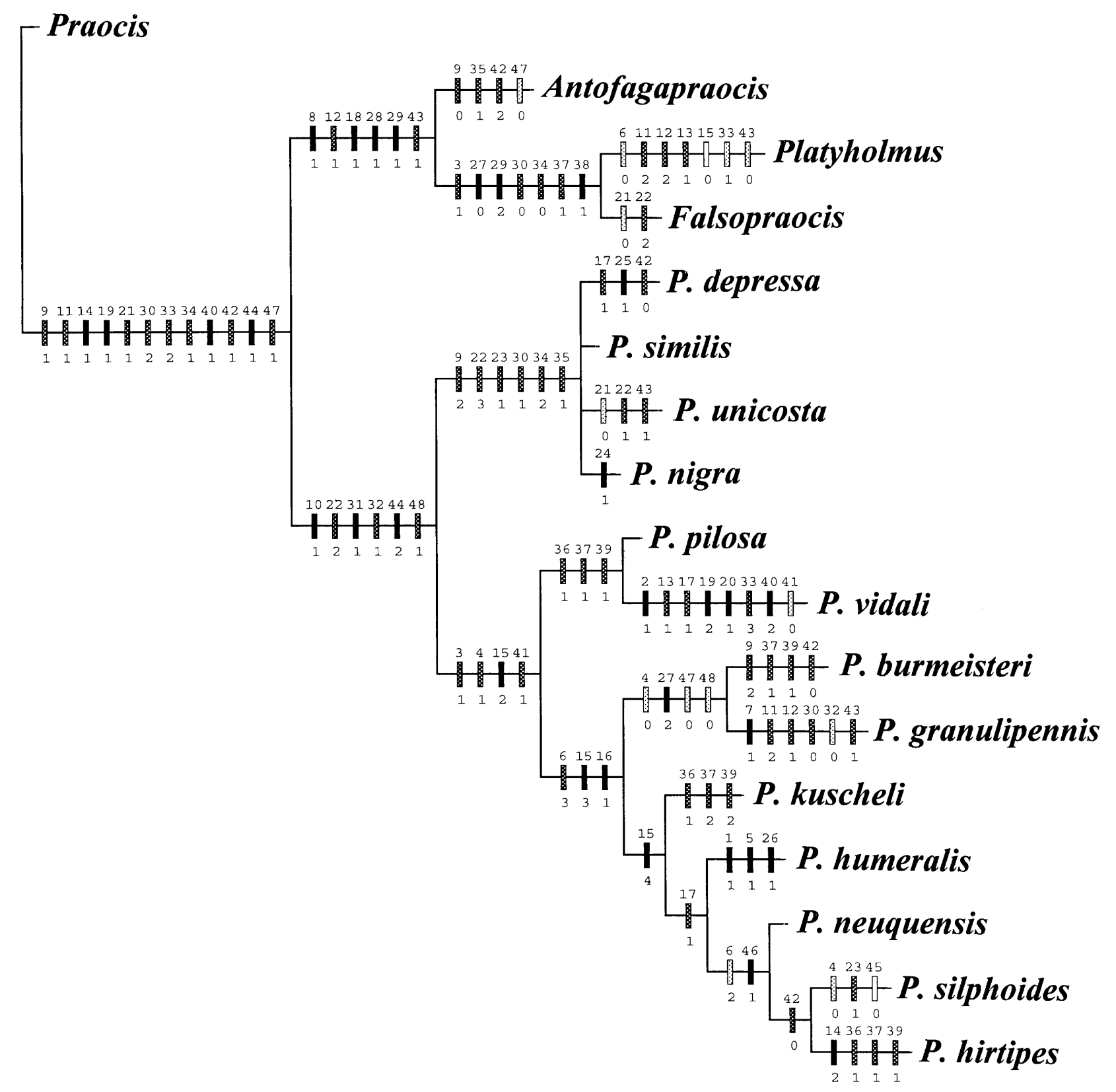

Fig. 42. Cladogram showing relationships of species of Platesthes. Black squares: non-homoplasious apomorphies; dotted squares: homoplasies.

Procedure. The data matrix (Appendix 2) was analyzed with NONA version 2.0 (Goloboff, 1993), applying the command sequence hold 1,000; hold 50; mult* 20 , and max*. The consistency and retention indices (Farris, 1989) were calculated including and excluding autapomorphies (characters 1, 2, 5, 20, 25, and 26). Clados version 1.8.1 (Nixon, 1993) was employed to examine the character distribution and print the cladogram.

Results. The analysis of the data matrix (Appendix 2) produced one most parsimonious cladogram (Fig. 42) 109 steps long, with a consistency index (CI) of 0.65 and a retention index (RI) of 0.72. Excluding autapomorphies the consistency index $(\mathrm{CI})$ is 0.63 . The monophyly of Platesthes is established by three unambiguous synapomorphies (Fig. 42): antennae longer in the male (10.1), epipleuron conspicuous in posterior 4/5 (31.1) and setae of lateral styles of tegmen on ventral surface, lateral margins and dorsal surface (44.2). The cladogram shows three other character states $(22.2,32.1$ and 48.1) that support the monophyly of Platesthes (Fig. 42), from which 22.2 (elytra with two main carinae, internal longer than external) evolves to state 3 (elytra with two main carinae, external and internal of same length) in the clade Platesthes depressa, P. similis, $P$. unicosta and $P$. nigra and then evolves to state 1 (elytra with one main carina) in $P$. unicosta; the character state 32.1 (epipleuron texture similar to that of elytron) shows a reversal to plesiomorphic state 0 (epipleuron texture different from that of elytron), in $P$. granulipennis; and the character state 48.1 (apicodorsal lobe of coxite extending about $1 / 4$ length of 
coxite) shows a reversal to plesiomorphic state 0 (apicodorsal lobe of coxite extending about $1 / 2$ length of coxite) in the clade $P$. burmeisteri and $P$. granulipennis.

Examination of the morphology of species from the remaining genera of Praocini not used as outgroups in this analysis, revealed that the character states epipleuron conspicuous in posterior 4/5 (31.1) and setae of lateral styles of tegmen on ventral surface, lateral margins and dorsal surface (44.2) are unique to Platesthes.

The species of Platesthes are grouped in two clades (Fig. 42), the first includes four species in an unresolved politomy. The second clade includes the remaining nine species of Platesthes, in which the relationships are resolved and some of its subclades are supported by the character states punctures on the frons $(6.2,6.3)$ and pronotum $(15.2,15.3$, and 15.4$)$, which are unique within the Praocini.

\section{DISCUSSION}

The first clade of species of Platesthes includes $P$. depressa, $P$. similis, $P$. unicosta and $P$. nigra (Fig. 42), which occur from south of the Santa Cruz River to north of Tierra del Fuego island (Figs 40, 41) (with the exception of $P$. unicosta, which occurs northwest of the source of the Santa Cruz River). The remaining nine species of Platesthes in the second clade are distributed from north of the Santa Cruz River to Neuquén in Argentina and reach Region VII in Central Chile (Figs 40, 41) (with the exception of $P$. granulipennis, which occurs on both sides of the Santa Cruz River). The valley of the Santa Cruz River was covered by ice repeatedly, during the Pliocene and Pleistocene glaciations (Mercer, 1976), which could have acted as a vicariant event separating populations to the north and south of the valley. The Santa Cruz River is a biogeographic barrier as is shown by the distribution of other genera of Tenebrionidae, such as Psectrascelis Solier, 1836 (Peña, 1985) and Patagonogenius Flores, 1999 (Flores, 1999), which do not occur south of the Santa Cruz River.

The distribution of the species of the two clades of Platesthes coincides approximately with the boundaries of the three districts recognized by Morrone et al. (2002) for the Central Patagonia biogeographic province: the four species of the first clade (Platesthes depressa, $P$. similis, $P$. unicosta and $P$. nigra) inhabit the Fuegian district (Figs 40, 41), while the species of the second clade inhabit the Payunia district ( $P$. neuquensis) and the Central district (the remaining species) (Figs 40, 41), reaching also to the Region VII in Central Chile ( $P$. vidali).

From a biodiversity conservation perspective, the distribution of Platesthes in the Patagonian steppes is subject to threats from livestock grazing and mining, which lead to habitat destruction (Flores, 1998). The distribution of Platesthes in the Patagonian steppes includes 16 protected zones (Table 1), which represent less than $1 \%$ of the total area of distribution of the genus in this area. This percentage is low, because a biome is poorly represented when less than $3 \%$ of it is protected and adequately represented when it is more than 10\% (Roig-Juñent \& Claver,
1999). These protected zones fall in the area of distribution of 10 of the 12 species of Platesthes. There are no protected zones for species with small areas of distribution such as $P$. humeralis and $P$. hirtipes. On the Patagonian steppes, most of the reserves are isolated and remote (Flores \& Roig Juñent, 2001), and are as biological islands within modified ecosystems (Halffter \& Ezcurra, 1992).

TABLE 1. Protected zones in the areas of distribution of Platesthes. A - Argentina; C - Chile.

\begin{tabular}{ll}
\hline Fuegian district & Reserva Provincial Dicky (A) \\
& Reserva Provincial Cabo Vírgenes (A) \\
& Reserva Provincial Laguna Azul (A) \\
& Reserva Municipal Laguna Nimez (A) \\
& Parque Nacional Los Glaciares (A) \\
& Parque Nacional Torres del Paine (C) \\
Central district & Reserva Provincial Península San Julián (A) \\
& Reserva Provincial Ría de Puerto Deseado (A) \\
& Monumento Natural Bosques Petrificados (A) \\
& Reserva Provincial Cabo dos Bahías (A) \\
& Reserva Provincial Punta Tombo (A) \\
& Reserva Faunística Península Valdés (A) \\
& Reserva Provincial Trevelín (A) \\
& Parque Nacional Los Alerces (A) \\
& Parque Nacional Nahuel Huapi (A) \\
Payunia district & Parque Nacional Laguna Blanca (A) \\
Southern & Reserva Nacional Radal (C) \\
Andean & Reserva Nacional Alto de Vilches (C) \\
Mountain range & Reserva Nacional Altos de Lircay (C) \\
& Parque Nacional Laguna del Laja (C) \\
\hline
\end{tabular}

The distribution of Platesthes vidali in Central Chile falls within the Southern Andean Mountain range entomofaunal region (Peña, 1966a). This area has been ranked by Flores \& Vidal (2000) as the first for conservation priority of the areas of endemism of the tenebrionid genus Callyntra Solier, 1836 using the cladistic indices of VaneWright et al. (1991). These authors emphasized the necessity for creating more reserves in this area, which has only four protected areas (Table 1) and specimens of $P$. vidali have been collected in three of these.

\section{CONCLUSIONS}

A cladistic analysis of Platesthes reveals that this genus is a monophyletic group defined by three synapomorphies of external morphology and male genitalia. Other character states, such as the punctures on frons and pronotum are unique to Platesthes among the Praocini and support subclades of species. Phylogenetic analysis indicates that the species of Platesthes are arranged in two monophyletic groups, which allows the proposal of a biogeographic evolutionary scenario.

Preliminary observations on the status of conservation of Platesthes in its area of distribution indicates that species of this genus are inadequately protected. Further studies of the taxa inhabiting mainly the Patagonian steppes are required to identify additional areas in need of conservation. 
ACKNOWLEDGEMENTS. I gratefully acknowledge curators for the loan of material; S. Roig Juñent, C.A. Triplehorn and two anonymous reviewers for suggestions for improving this paper; S. Roig Juñent for the use of NONA, K.C. Nixon for the use of Clados; O. Merkl for providing helpful information about the location of the types of Kulzer, P. Sackmann for sending information on the habitat of Platesthes pilosa, O. Villegas for taking the photographs and my wife Claudía Vergara for help in preparation of artwork and help in the field trip to Santa Cruz province in 1998. This study was supported by a re-entry fellowship of the Consejo Nacional de Investigaciones Científicas y Técnicas (CONICET), Argentina, and a re-entry grant of the Antorchas Foundation, Argentina.

\section{REFERENCES}

Arnett JR. R.H., SAmuelson G.A. \& Nishida G.M. 1993: The Insect and Spider Collections of the World. 2nd ed. Sandhill Crane Press, Gainesville, Florida, 310 pp.

Berg F.G.C. 1899: Coleópteros de la Tierra del Fuego, coleccionados por el Sr. Carlos Bachausen. Comun. Mus. Nac. B. Aires 1(3): 57-65.

BLACKWELDER R.E. 1945: Checklist of the coleopterous insects of Mexico, Central America, the West Indies and South America. Part 3. Bull. U.S. Nat. Mus. 185: 343-550.

Blanchard C.E. 1853: Insectes. In: Voyage au Pole Sud et dans l'Océanie sur les corvettes l'Astrolabe et la Zélée; exécuté par ordre du Roi pendant les années 1837-1838-1839-1840 sous le commandement de M.J. Dumont-d'Urville, Capitaine de vaisseau. Zoologie, Vol. 4, Part 1. Baudry, Paris, 422 pp.

Bruch C. 1915: Catálogo Sistemático de los coleópteros de la República Argentina. Pars VI. Rev. Mus. La Plata (Ser. 2) 19: 235-302.

Burmeister H. 1875: Melanosoma Argentina. Stettin. Entomol. Ztg 36: 457-500.

Champion G.C. 1895: A list of Tenebrionidae supplementary to the "Munich" Catalogue. Mém. Soc. Entomol. Belg. 3: 1-264.

Doyen J.T. 1993: Cladistic relationships among Pimeliinae Tenebrionidae (Coleoptera). J. N. Y. Entomol. Soc. 101: 443-514.

FAIRMAIRE L. 1883: Note sur quelques coléoptères de Magellan et de Santa Cruz. Ann. Soc. Entomol. Fr. (Ser. 6) 3: 483-506.

Fairmaire L. 1889: Insectes de Patagonie. Coléoptères. Nouv. Archs Mus. Hist. Nat. (Ser. 3) Vol. 1. pp. 101-137.

FARRIS J.S. 1989: The retention index and the rescaled consistency index. Cladistics 5: 417-419.

Flores G.E. 1996: Estudio comparativo de las estructuras genitales en la tribu Nycteliini (Coleoptera: Tenebrionidae). Rev. Soc. Entomol. Argent. 55: 33-48.

FloRes G.E. 1997: Revisión de la tribu Nycteliini (Coleoptera: Tenebrionidae). Rev. Soc. Entomol. Argent. 56: 1-19.

Flores G.E. 1998: Tenebrionidae. In Morrone J.J. \& Coscarón S. (eds): Biodiversidad de artrópodos argentinos: Una perspectiva biotaxonómica. Ediciones Sur, La Plata, Argentina, pp. 232-240.

FLORES G.E. 1999: Systematic revision and cladistic analysis of the Neotropical genera Mitragenius Solier, Auladera Solier and Patagonogenius gen. n. (Coleoptera: Tenebrionidae). Entomol. Scand. 30: 361-396.

Flores G.E. 2000a: Systematics of the Andean genera Falsopraocis Kulzer and Antofagapraocis gen. n. (Coleoptera: Tenebrionidae), with descriptions of two new species. J. N. Y. Entomol. Soc. 108: 52-75.

FLORES G.E. 2000b: Systematic revision of the Argentinean genus Thylacoderes Solier (Coleoptera: Tenebrionidae), with descriptions of two new species. J. N. Y. Entomol. Soc. 108: 76-94.

FLores G.E. 2001: Taxonomic placement of the Andean genera Praocidia Fairmaire and Pilobaloderes Kulzer (Coleoptera: Tenebrionidae: Praocini). J. N. Y. Entomol. Soc. 109: 171-178.

Flores G.E. \& RoIG-Juñent S. 2001: Cladistic and biogeographic analyses of the Neotropical genus Epipedonota Solier (Coleoptera: Tenebrionidae), with conservation considerations. J. N. Y. Entomol. Soc. 109: 309-336.

Flores G.E. \& Vidal P. 2000: Cladistic analysis of the Chilean genus Callyntra Solier (Coleoptera: Tenebrionidae), with description of a new species. J. N. Y. Entomol. Soc. 108: 187-204.

Gajardo R. 1994: La vegetación natural de Chile. Clasificación $y$ distribución geográfica. University of Santiago, Santiago, $165 \mathrm{pp}$.

Gebien H. 1910: Tenebrionidae. II. In Junk W. \& Schenkling S. (eds): Coleopterorum Catalogus XVIII. Pars 22. W. Junk, Berlin, pp. 167-354.

Gebien H. 1938. Katalog der Tenebrioniden. Teil II. Mitt. Münch. Entomol. Ges. 28: 397-428.

Gemminger M. \& Harold E. von 1870: Catalogus Coleopterorum huicusque descriptorum synonymicus et systematicus. Vol. 7. S. Gummi, Monachii, pp. 1801-2180.

GolobofF P.A. 1993: NONA version 2.0. A tree searching program. MS-Dos program and documentation, distributed by the author.

GuÉRIN-MÉNÉVILLE F.E. 1841: Description de quelques coléoptères nouveaux provenant des Iles Auckland, de Triton Bay, des Iles Salomon et du Port Famine, dans le Détroit de Magellan. Rev. Zool. 4: 213-217.

Haag-Rutenberg J.G. 1877: Genus Platesthes Waterh. Stett. Entomol. Ztg 38: 155-156.

Halffter G. \& Ezcurra E. 1992: Qué es la biodiversidad? In Halffter G. (ed.): La Diversidad Biológica de Iberoamérica. CYTED-D, Mexico D.F., pp. 3-24.

KASZAB Z. 1964: The zoological results of Gy. Topál's collectings in South Argentina. 13. Coleoptera-Tenebrionidae. Ann. Hist.-Nat. Mus. Natn. Hung. 56: 353-387.

Kolbe H: 1907: Coleopteren. Ergebn. Hamburger Magalhaen. Sammel. 8(4): 1-125.

Kulzer H. 1956: Neue Tenebrioniden aus Südamerika (15 Beitrag zur Kenntnis der Tenebrioniden). Die Gattung Platesthes Wat. (Praocini). Entomol. Arb. Mus. Georg Frey 7: 952-960.

Kulzer H. 1958: Monographie der südamerikanischen Tribus Praocini (Col.) (16 Beitrag zur Kenntnis der Tenebrioniden). Entomol. Arb. Mus. Georg Frey 9: 1-105.

Kulzer H. 1962: Neue Tenebrioniden aus Südamerika (Col.) (23. Beitrag zur Kenntnis der Tenebrioniden). Entomol. Arb. Mus. Georg Frey 13: 79-100.

Kuschel G. 1969: Biogeography and ecology of South American Coleoptera. In Fittkau E.J., Illies J., Klinge H., Schwabe G.H. \& Sioli H. (eds): Biogeography and Ecology in South America. Vol. 2. Junk, The Hague, pp. 709-722.

LACORDAIRE J.T. 1859: Histoire Naturelle des Insectes. Genera des Coléoptères ou exposé méthodique et critique de tous les genres proposés jusqu'ici dans cet ordre d'insectes. Vol 5. Roret, Paris, $750 \mathrm{pp}$.

Marcuzzi G. 1991: Tenebrionidi e Zoferidi (Coleoptera: Heteromera) raccolti in Subantartide. Animalia 18: 175-205.

Mercer J.H. 1976: Glacial history of southernmost South America. Quat. Res. 6: 125-166.

Morrone J.J. 2001: Biogeografía de América Latina y el Caribe. Manuales \& Tesis Sociedad Entomológica Aragonesa, Vol. 3. Zaragoza, Spain, 148 pp. 
Morrone J.J., Roig-Juñent S. \& Flores G.E. 2002: Delimitation of biogeographic districts in central Patagonia (southern South America), based on beetle distributional patterns (Coleoptera: Carabidae and Tenebrionidae). Rev. Mus. Argent. Cienc. Nat. (N.S.) 4: 1-6.

Nixon K.C. 1993. Clados version 1.8.1 IBM PC-compatible character analysis program. Published by the author, Cornell University, Ithaca, New York.

NiXon K.C. \& CARPENTER J.M. 1993: On outgroups. Cladistics 9: $413-426$

Paruelo J.M., Beltrán A., Jobbagy E., Sala O. \& Golluscio R.A. 1998: The climate of Patagonia: general patterns and controls on biotic processes. Ecol. Austral 8: 85-101.

PeÑA L.E. 1966a: A preliminary attempt to divide Chile into entomofaunal regions, based on the Tenebrionidae (Coleoptera). Postilla 97: 1-17.

PeÑa L.E. 1966b: Catálogo de los Tenebrionidae (Coleoptera) de Chile. Entomol. Arb. Mus. Georg Frey 17: 397-453.

Peña L.E. 1985: Revisión del género Psectrascelis Solier (Coleoptera: Tenebrionidae). Rev. Chil. Entomol. 12: 15-51.

PeÑa L.E. 1986: Descripción de cinco nuevas especies de Tenebrionidae (Coleoptera) de los géneros Psectrascelis, Platesthes y Thinobatis con una nota adicional. Rev. Chil. Entomol. 14: 57-63.

Philippi F.H. 1887: Catálogo de los Coleópteros de Chile. An. Univ. Chile 71: 619-806.

Roig Juñent S. \& Claver S. 1999: La entomofauna del Monte y su conservación en las áreas naturales protegidas. Rev. Soc. Entomol. Argent. 58 (1-2): 117-127.

Solier A.J.J. 1851: Fauna chilena: Coleópteros. In Gay C.: Historia Física y Política de Chile. Zoología. Vol. 5. Maulde et Renou, Paris, pp. 183-204.

Strong E.E. \& LiPscomb D.L. 1999: Character coding and inapplicable data. Cladistics 15: 363-371.

TSCHINKEL W.R. \& Doyen J.T. 1980: Comparative anatomy of the defensive glands, ovipositors and female genital tubes of tenebrionid beetles (Coleoptera). Int. J. Insect Morphol. \& Embryol. 9: 321-368.

Vane-Wright R.I., Humphries C.J. \& Williams P.H. 1991: What to protect? Systematics and the agony of choice. Biol. Conserv. 55: 235-254.

Waterhouse G.R. 1845: Description of some new genera and species of Heteromerous Coleoptera. Ann. Mag. Nat. Hist. 16: 317-324.

WiLKINSON M. 1992: Ordered versus unordered characteres. Cladistics 8: 375-385.

ApPENDIX 1. Characters and character states used in the cladistic analysis of Platesthes $(0$ - plesiomorphic; 1, 2, 3, 4- apomorphic)

Head

1. Labrum, anterior margin: concave (0); "V"-shaped (1).

2. Clypeus: straight (0); bent downward (1).

3. Clypeal suture: clypeus and frons at same level (0); clypeus lower than frons (1).

4. Clypeal suture: not covered by frons (0); covered by frons (1).

5. Clypeus, punctures: round with a central seta (0); round with a seta on posterior margin (1).

6. Frons, punctures: absent (0); round with a central seta (1); round with a seta on posterior margin (2); semicircular, with a seta on posterior margin (3).

7. Frons, distance between punctures, if present: much greater than diameter of one puncture (0); less than diameter of one puncture (1).
8. Maxillary palps, last segment: axe-shaped (0); subcylindrical (1).

9. Groove between eye and frons: absent (0); present on entire dorsal margin of eye (1), present only on posterior half of dorsal margin of eye (2).

10. Antennal length: equal in both sexes $(0)$; longer in the male (1).

11. Antennal length male: reaching the middle of lateral margin of pronotum (0); reaching 3/4 along lateral margin of pronotum (1); reaching posterior margin of pronotum (2).

12. Antennal length female: reaching the middle of lateral margin of pronotum (0); reaching 3/4 along lateral margin of pronotum (1); reaching posterior margin of pronotum (2).

13. Antennomere 10, width: wider than long (Fig. 18) (0); longer than wide (Fig. 19) (1).

14. Antennomere 11, width: not exceeding width of 9 th $(0)$; equal to width of 9 th (Fig. 19) (1); exceeding width of 9 th (Fig. 18) (2).

Thorax

15. Pronotum, punctures: absent (0); round with a central seta (Fig. 32) (1); round with a seta on anterior margin (Fig. 33) (2); semicircular with a seta on anterior margin (Fig. 34) (3); triangular with a seta on anterior margin (Fig. 35) (4).

16. Pronotum, distance between punctures, if present: much greater than diameter of one puncture (Figs 32, 33) (0); equal or less than diameter of one puncture (Figs 34, 35) (1).

17. Lateral margin of pronotum: not raised (0); raised (1).

18. Lateral margin of pronotum: remote from disc $(0)$; contiguous with disc (1).

19. Posterior angles of pronotum: acute (0); obtuse (Figs 20-24) (1); straight (Fig. 25) (2).

20. Disc of pronotum: convex, higher than lateral margins (0); flat, at lower level than lateral margins (1).

21. Prosternum, shape: flat (0); convex (1).

Elytron

22. Carinae: absent (0); one (1); two, internal longer than external (Figs 37-39) (2), two, external and internal of same length or external longer than internal (Fig. 36) (3).

23. Carinae, if present: equidistant between suture and lateral margin (Figs 37-39) (0); more approximate to a lateral margin (Fig. 36) (1).

24. Carinae, if present: reaching the end of elytron (0); reaching to half or $3 / 4$ the length of the elytron (1).

25. Elytron: arched (Figs 37-39) (0); flat (Fig. 36) (1).

26. Elytral humeri: not raised (Figs 36-37, 39) (0); very expanded and raised (Fig. 38) (1).

27. Elytral punctures: absent (0); round, with anterior margin not raised (1); round, with anterior margin raised appearing as protuberances (2).

28. Lateral margin: glabrous (0); with setae (1).

29. Lateral margin surface: smooth $(0)$; punctate (1); with protuberances (2).

30. Pseudopleuron surface: with protuberances (0); with sparse punctures (1); with abundant punctures (2).

31. Epipleuron: conspicuous throughout (0); conspicuous in posterior $4 / 5$ (1).

32. Epipleuron, texture: different from that of elytron (0); similar to that of elytron (1).

33. Epipleuron, anterior quarter: four times as wide as posterior half (0); three times as wide as posterior half (1); twice as wide as posterior half (2); 1.5 times as wide as posterior half (3).

34. Epipleuron surface: with protuberances (0); punctate (1); smooth (2).

35. Epipleuron surface: with setae (0); glabrous (1).

Legs 
36. Ventral surface of trochanters: with uniform pubescence (0); with brush-like pubescence (1).

37. Ventral femoral surface: with uniform pubescence $(0)$; densely setose throughout (1); densely setose on proximal half (2).

38. Setae on ventral femoral surface: arising in punctures $(0)$; arising in protuberances (1).

39. Ventral tibial surface: with uniform pubescence (0); densely setose throughout (1); densely setose on distal half (2).

40. Protibiae, width of distal margin: exceeding $1 / 3$ protibial length, but not exceeding half protibial length (0); equal to $1 / 4$ protibial length (1); equal to $1 / 5$ protibial length (2).

41. Setae on ventral surface of tarsi: sparse (0); abundant (1).

Male genitalia

42. Lateral styles of tegmen: ventrally concave (Fig. 14) (0); ventrally bisinuate (Fig. 12) (1); ventrally triangular (2).
43. Lateral styles of tegmen: not overlapping dorsally median lobe (Fig. 13) (0); projecting dorsally over median lobe (Fig. 11) (1).

44. Setae of lateral styles of tegmen: on ventral surface and lateral margins $(0)$; only on lateral margins (1); on ventral surface, lateral margins and dorsal surface (Figs 11-14) (2).

45. Lateral styles of tegmen: widest at distal third (Fig. 14) (0); widest at base (Fig. 12) (1).

46. Base of basal lamina of tegmen: concave (Fig. 12) (0); straight (Fig. 14) (1).

Female genitalia

47. Paraprocts: with setae (0); glabrous (1).

48. Proctiger, extent of apicodorsal lobe: extending about $1 / 2$ length of coxite ( 0 ); extending about $1 / 4$ length of coxite (1).

Received August 28, 2003; revised January 12, 2004; accepted April 5, 2004

Appendix 2. Data matrix of species of Platesthes (plus the outgroups Praocis, Antofagapraocis, Platyholmus and Falsopraocis). $0-4=$ character states $(0=$ plesiomorphic; $1,2,3,4=$ apomorphic $)$; a (polymorphy $)=0 / 1 ;-=$ inapplicable.

Taxa
Praocis
Antofagapraocis
Platyholmus
Falsopraocis
P. depressa
P. similis
P. unicosta
$P$. nigra
$P$. pilosa
P. vidali
P. burmeisteri
$P$. granulipennis
P. humeralis
P. kuscheli
$P$. neuquensis
$P$. silphoides
$P$. hirtipes

Characters

$1111111112 \quad 2222222223 \quad 3333333334 \quad 44444444$

$\begin{array}{lllllll}1234567890 & 1234567890 & 1234567890 & 1234567890 & 12345678\end{array}$

$0000010000 \quad 0000100000 \quad 00--001000000000000000001000$

$0000010100 \quad 1101100110 \quad 10--001112002110000102111000$

$001000-11022110-0110 \quad 10--000120001000110101011010$

$0010010110 \quad 11011001100200000120002000110101111010$

000001002110011010101310101001112210000100021011

$000001002110011000101310001001 \quad 112210000101021011$

$000001002110011000100110001001 \quad 112210000101121011$

$0000010021 \quad 1001100010 \quad 1311001001 \quad 112210000101021011$

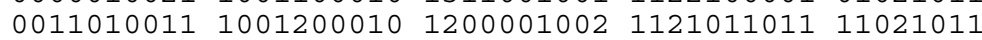

$0111010011 \quad 1011201021 \quad 1200001002113101101201021011$

$00100300211001310010 \quad 1200002002 \quad 112102101110021000$

$001003101121013100101200002000 \quad 102100000111121000$

$1011130011 \quad 1001411010 \quad 1200011002 \quad 112100000111021011$

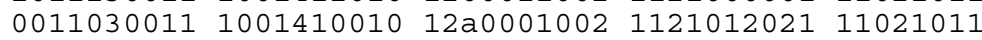

$00110200111001411010 \quad 1200001002 \quad 112100000111021111$

001002001110014110101210001002112100000110020111

001102001110024110101200001002112101101110021111 